\title{
LEVEL II SCOUR ANALYSIS FOR BRIDGE 21 (WALDTH00450021) on TOWN HIGHWAY 45, crossing JOES BROOK, WALDEN, VERMONT
}

Open-File Report 97-799

Prepared in cooperation with

VERMONT AGENCY OF TRANSPORTATION

and

FEDERAL HIGHWAY ADMINISTRATION

U.S. Department of the Interior

U.S. Geological Survey

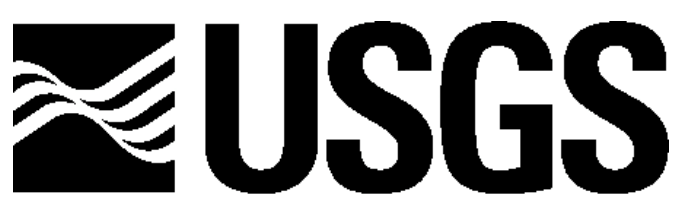

science for a changing world 


\section{LEVEL II SCOUR ANALYSIS FOR}

BRIDGE 21 (WALDTH00450021) on

TOWN HIGHWAY 45, crossing

JOES BROOK,

WALDEN, VERMONT

By MICHAEL A. IVANOFF AND LAURA MEDALIE

U.S. Geological Survey

Open-File Report 97-799

Prepared in cooperation with

VERMONT AGENCY OF TRANSPORTATION

and

FEDERAL HIGHWAY ADMINISTRATION 


\title{
U.S. DEPARTMENT OF THE INTERIOR BRUCE BABBITT, Secretary
}

\author{
U.S. GEOLOGICAL SURVEY \\ Mark Schaefer, Acting Director
}

For additional information write to:

District Chief

U.S. Geological Survey 361 Commerce Way

Pembroke, NH 03275-3718
Copies of this report may be purchased from:

U.S. Geological Survey

Branch of Information Services

Open-File Reports Unit

Box 25286

Denver, CO 80225-0286 


\section{CONTENTS}

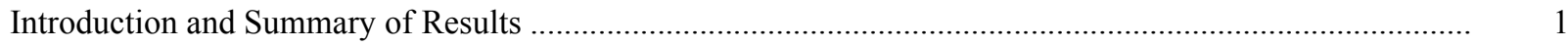

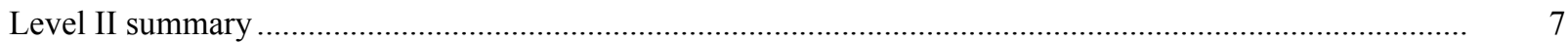

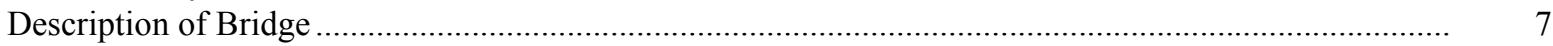

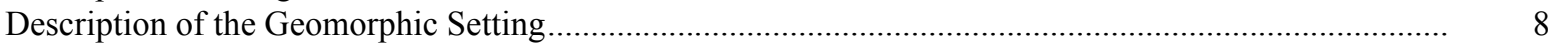

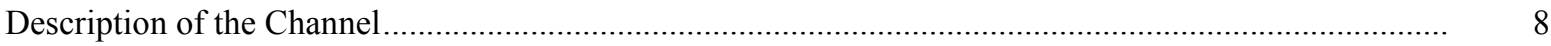

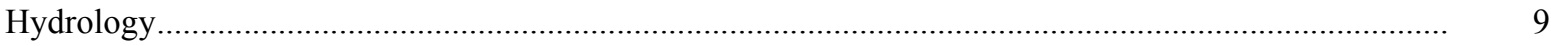

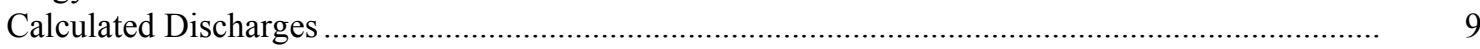

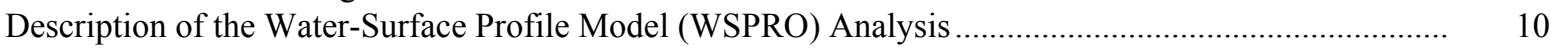

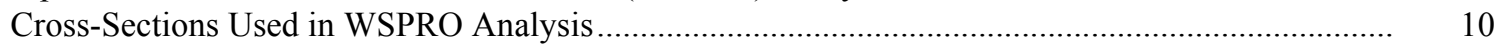

Data and Assumptions Used in WSPRO Model ..................................................................... 11

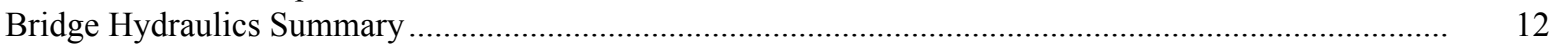

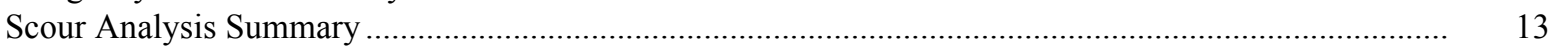

Special Conditions or Assumptions Made in Scour Analysis ...................................................... 13

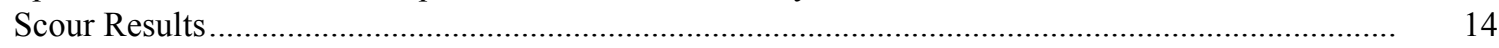

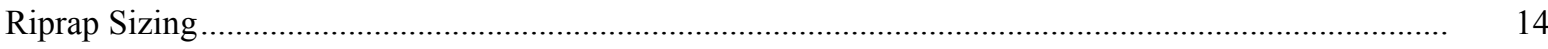

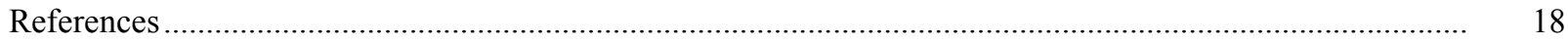

Appendixes:

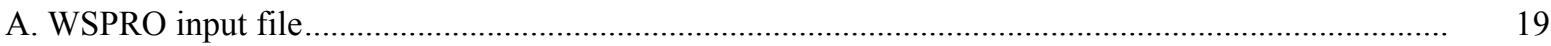

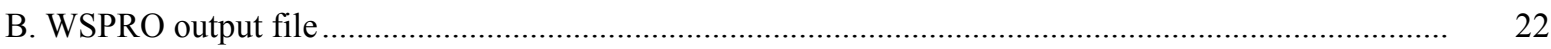

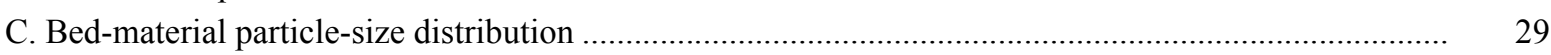

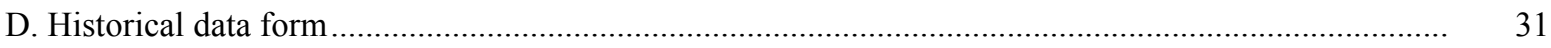

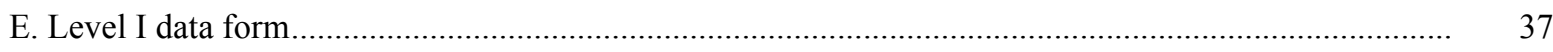

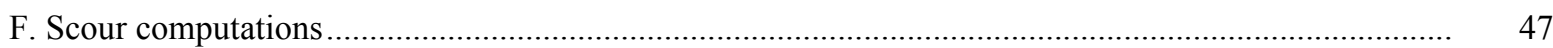

\section{FIGURES}

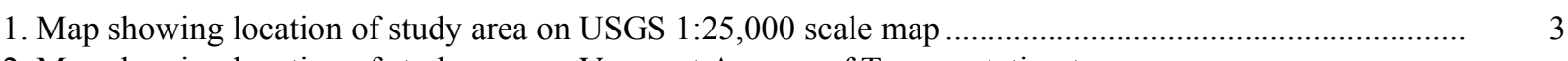

2. Map showing location of study area on Vermont Agency of Transportation town
highway map

3. Structure WALDTH00450021 viewed from upstream (July 27, 1995) ..................................................

4. Downstream channel viewed from structure WALDTH00450021 (July 27, 1995) ............................... 5

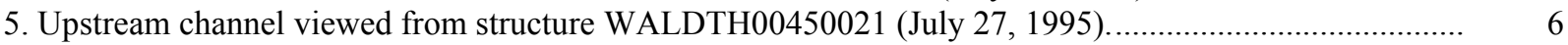

6. Structure WALDTH00450021 viewed from downstream (July 27, 1995). ......................................... 6

7. Water-surface profiles for the 100- and 500-year discharges at structure

WALDTH00450021 on Town Highway 45, crossing Joes Brook,

Walden, Vermont.

8. Scour elevations for the 100- and 500-year discharges at structure

WALDTH00450021 on Town Highway 45, crossing Joes Brook,

Walden, Vermont.

\section{TABLES}

1. Remaining footing/pile depth at abutments for the 100-year discharge at structure

WALDTH00450021 on Town Highway 45, crossing Joes Brook,

Walden, Vermont

2. Remaining footing/pile depth at abutments for the 500-year discharge at structure

WALDTH00450021 on Town Highway 45, crossing Joes Brook,

Walden, Vermont

5

5

6

6




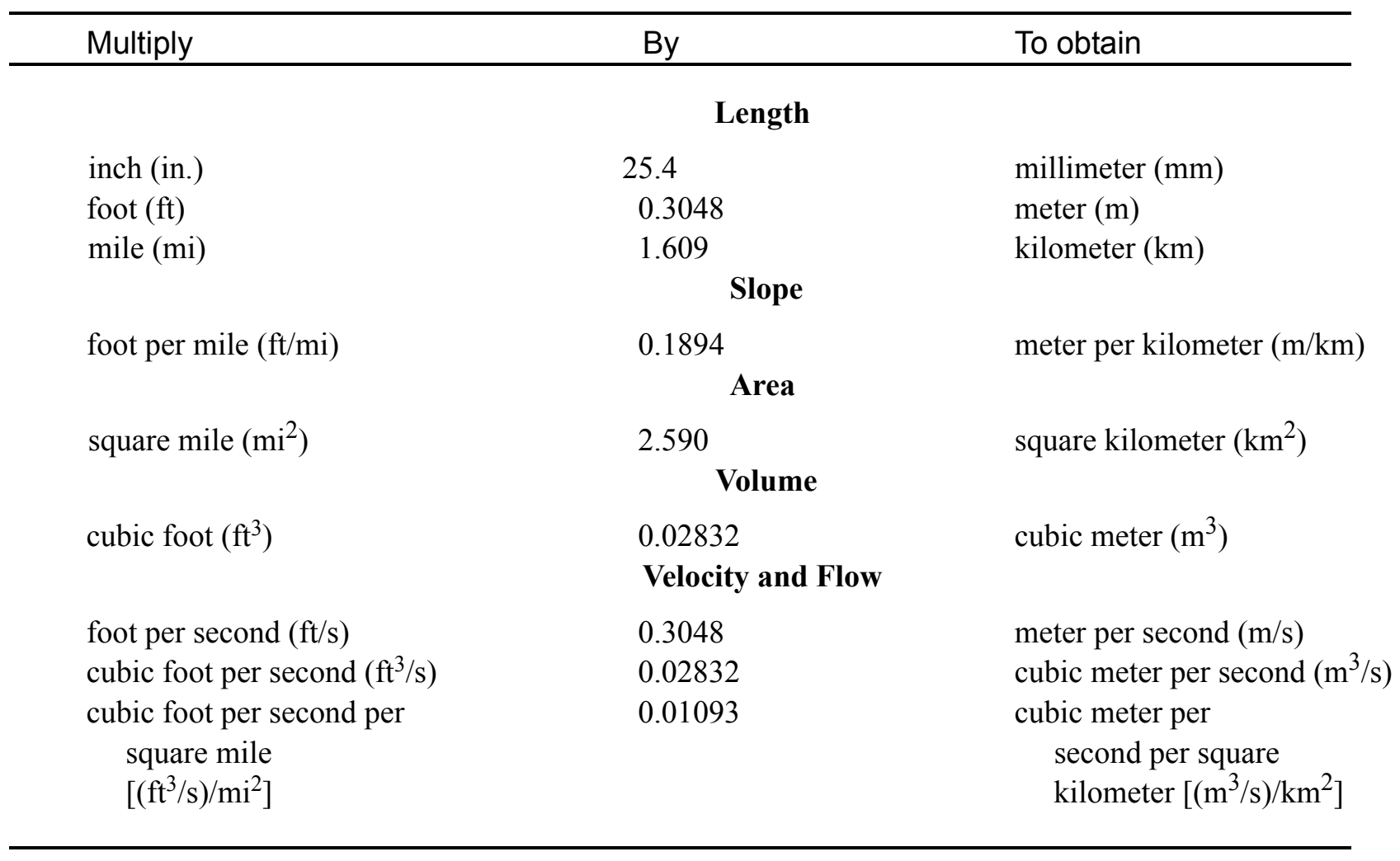

\section{OTHER ABBREVIATIONS}

$\begin{array}{lrlr}\mathrm{BF} & \text { bank full } & \text { LWW } & \text { left wingwall } \\ \mathrm{cfs} & \text { cubic feet per second } & \text { MC } & \text { main channel } \\ \mathrm{D}_{50} & \text { median diameter of bed material } & \text { RAB } & \text { right abutment } \\ \mathrm{DS} & \text { downstream } & \text { RABUT } & \text { face of right abutment } \\ \mathrm{elev} & \text { elevation } & \text { RB } & \text { right bank } \\ \mathrm{f} / \mathrm{p} & \text { flood plain } & \text { ROB } & \text { right overbank } \\ \mathrm{ft}^{2} & \text { square feet } & \text { RWW } & \text { right wingwall } \\ \mathrm{ft} / \mathrm{ft} & \text { feet per foot } & \text { TH } & \text { town highway } \\ \mathrm{JCT} & \text { junction } & \text { UB } & \text { under bridge } \\ \mathrm{LAB} & \text { left abutment } & \text { US } & \text { upstream } \\ \mathrm{LABUT} & \text { face of left abutment } & \text { USGS } & \text { United States Geological Survey } \\ \mathrm{LB} & \text { left bank } & \text { VTAOT Vermont Agency of Transportation } \\ \mathrm{LOB} & \text { left overbank } & \text { WSPRO } & \text { water-surface profile model }\end{array}$

In this report, the words "right" and "left" refer to directions that would be reported by an observer facing downstream. Sea level: In this report, "sea level" refers to the National Geodetic Vertical Datum of 1929-- a geodetic datum derived from a general adjustment of the first-order level nets of the United States and Canada, formerly called Sea Level Datum of 1929.

In the appendices, the above abbreviations may be combined. For example, USLB would represent upstream left bank. 


\title{
LEVEL II SCOUR ANALYSIS FOR BRIDGE 21 (WALDTH00450021) ON TOWN HIGHWAY 45, CROSSING JOES BROOK, WALDEN, VERMONT
}

\author{
By Michael A. Ivanoff and Laura Medalie
}

\section{INTRODUCTION AND SUMMARY OF RESULTS}

This report provides the results of a detailed Level II analysis of scour potential at structure WALDTH00450021 on Town Highway 45 crossing Joes Brook, Walden, Vermont (figures 1-8). A Level II study is a basic engineering analysis of the site, including a quantitative analysis of stream stability and scour (U.S. Department of Transportation, 1993). Results of a Level I scour investigation also are included in Appendix E of this report. A Level I investigation provides a qualitative geomorphic characterization of the study site. Information on the bridge, gleaned from Vermont Agency of Transportation (VTAOT) files, was compiled prior to conducting Level I and Level II analyses and is found in Appendix D. The VTAOT files state that the stream is Coles Brook, both the USGS and the VTAOT maps state that it is Joes Brook.

The site is in the New England Upland section of the New England physiographic province in central Vermont. The $18.7-\mathrm{mi}^{2}$ drainage area is in a predominantly rural and forested basin. In the vicinity of the study site, the surface cover is pasture upstream and downstream of the bridge while the immediate banks have dense woody vegetation.

In the study area, Joes Brook has an incised, sinuous channel with a slope of approximately $0.01 \mathrm{ft} / \mathrm{ft}$, an average channel top width of $76 \mathrm{ft}$ and an average bank height of $5 \mathrm{ft}$. The channel bed material ranges from sand to boulder with a median grain size $\left(D_{50}\right)$ of 75.4 $\mathrm{mm}(0.247 \mathrm{ft})$. The geomorphic assessment at the time of the Level I and Level II site visit on July 27,1995 , indicated that the reach was stable.

The Town Highway 45 crossing of Joes Brook is a 35-ft-long, one-lane bridge consisting of one 29-foot steel-beam span with a wooden deck (Vermont Agency of Transportation, written communication, April 5, 1995). The opening length of the structure parallel to the bridge face is $26.2 \mathrm{ft}$. The bridge is supported by vertical, "laid-up" concrete block abutments with no wingwalls. The channel is skewed approximately zero degrees to the opening while the computed opening-skew-to-roadway is 5 degrees. 
The scour protection measures at the site included type-1 stone fill (less than 12 inches diameter) along the upstream left bank and along the entire base length of the left abutment. There is also type-2 stone fill (less than 36 inches diameter) along the entire base length of the right abutment. Additional details describing conditions at the site are included in the Level II Summary and Appendices D and $\mathrm{E}$.

Scour depths and recommended rock rip-rap sizes were computed using the general guidelines described in Hydraulic Engineering Circular 18 (Richardson and others, 1995) for the 100- and 500-year discharges. In addition, the incipient roadway-overtopping discharge is determined and analyzed as another potential worst-case scour scenario. Total scour at a highway crossing is comprised of three components: 1) long-term streambed degradation; 2) contraction scour (due to accelerated flow caused by a reduction in flow area at a bridge) and; 3 ) local scour (caused by accelerated flow around piers and abutments). Total scour is the sum of the three components. Equations are available to compute depths for contraction and local scour and a summary of the results of these computations follows.

Contraction scour for all modelled flows ranged from 0.0 to $1.5 \mathrm{ft}$. The worst-case contraction scour occurred at the incipient roadway-overtopping discharge, which was less than the 100-year discharge. Abutment scour ranged from 12.4 to $24.4 \mathrm{ft}$. The worst-case abutment scour occurred at the 500-year discharge. Additional information on scour depths and depths to armoring are included in the section titled "Scour Results". Scouredstreambed elevations, based on the calculated scour depths, are presented in tables 1 and 2. A cross-section of the scour computed at the bridge is presented in figure 8. Scour depths were calculated assuming an infinite depth of erosive material and a homogeneous particlesize distribution.

It is generally accepted that the Froehlich equation (abutment scour) gives "excessively conservative estimates of scour depths" (Richardson and others, 1995, p. 47). Usually, computed scour depths are evaluated in combination with other information including (but not limited to) historical performance during flood events, the geomorphic stability assessment, existing scour protection measures, and the results of the hydraulic analyses. Therefore, scour depths adopted by VTAOT may differ from the computed values documented herein. 


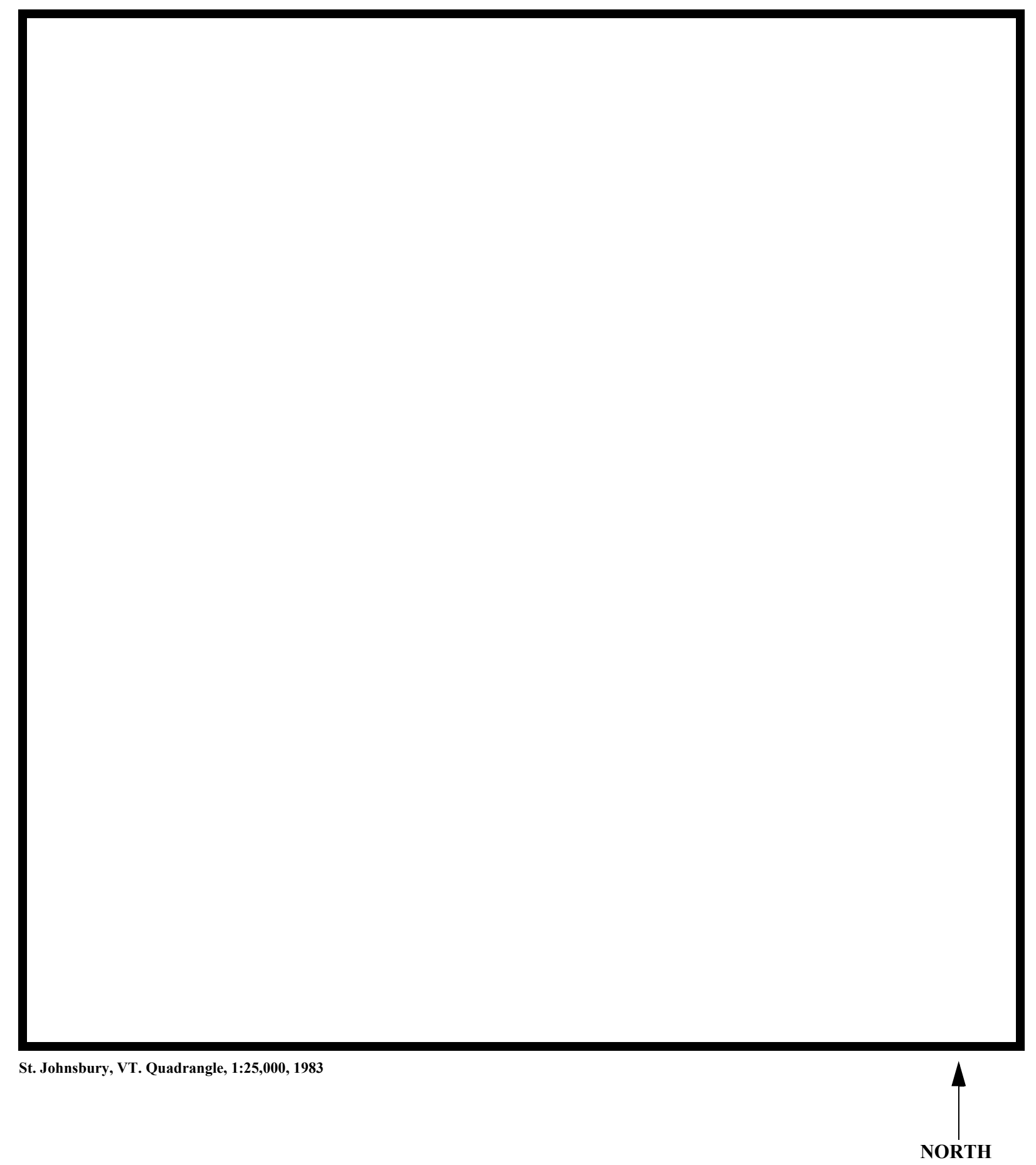

Figure 1. Location of study area on USGS 1:25,000 scale map. 
Figure 2. Location of study area on Vermont Agency of Transportation town highway map. 

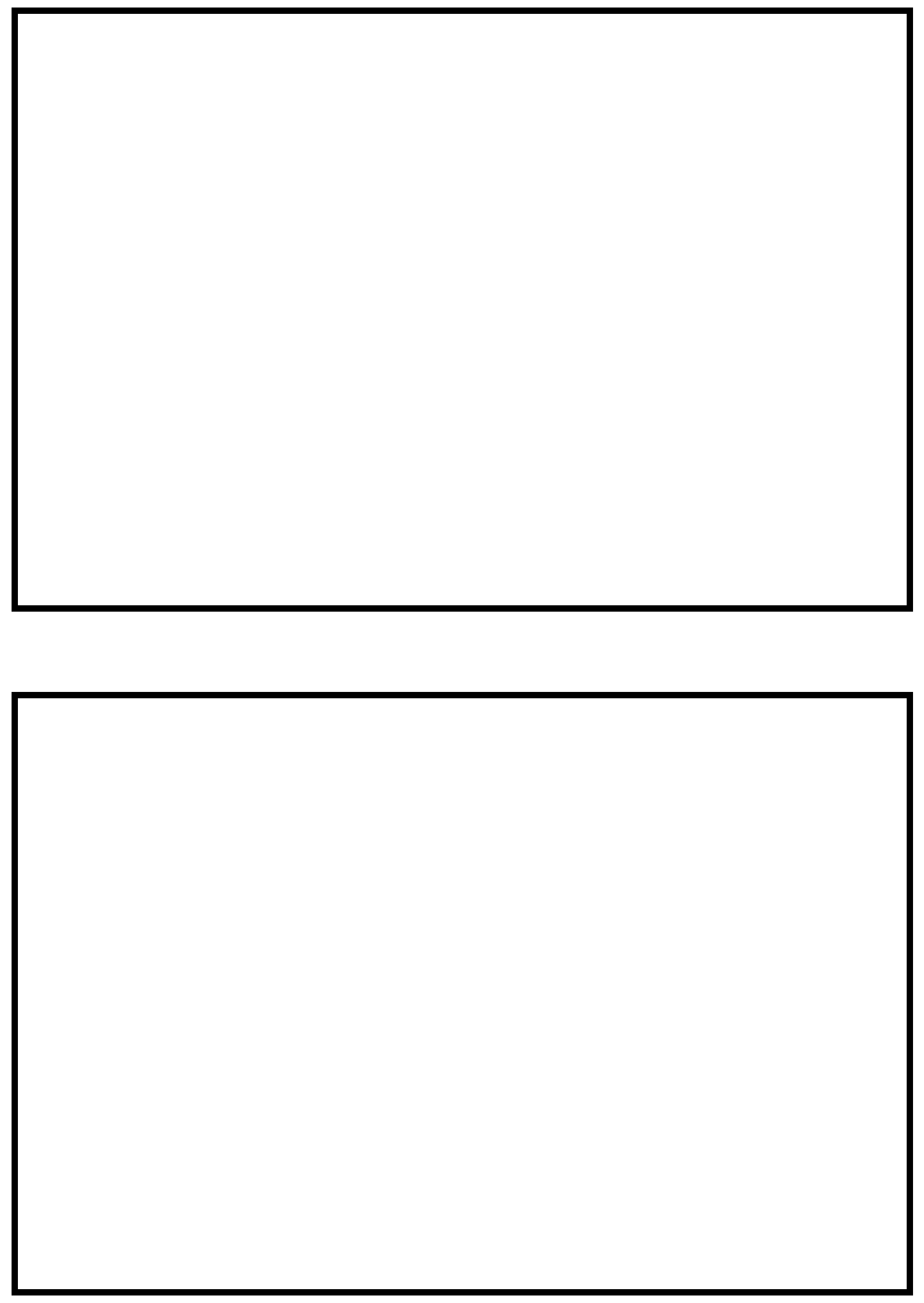

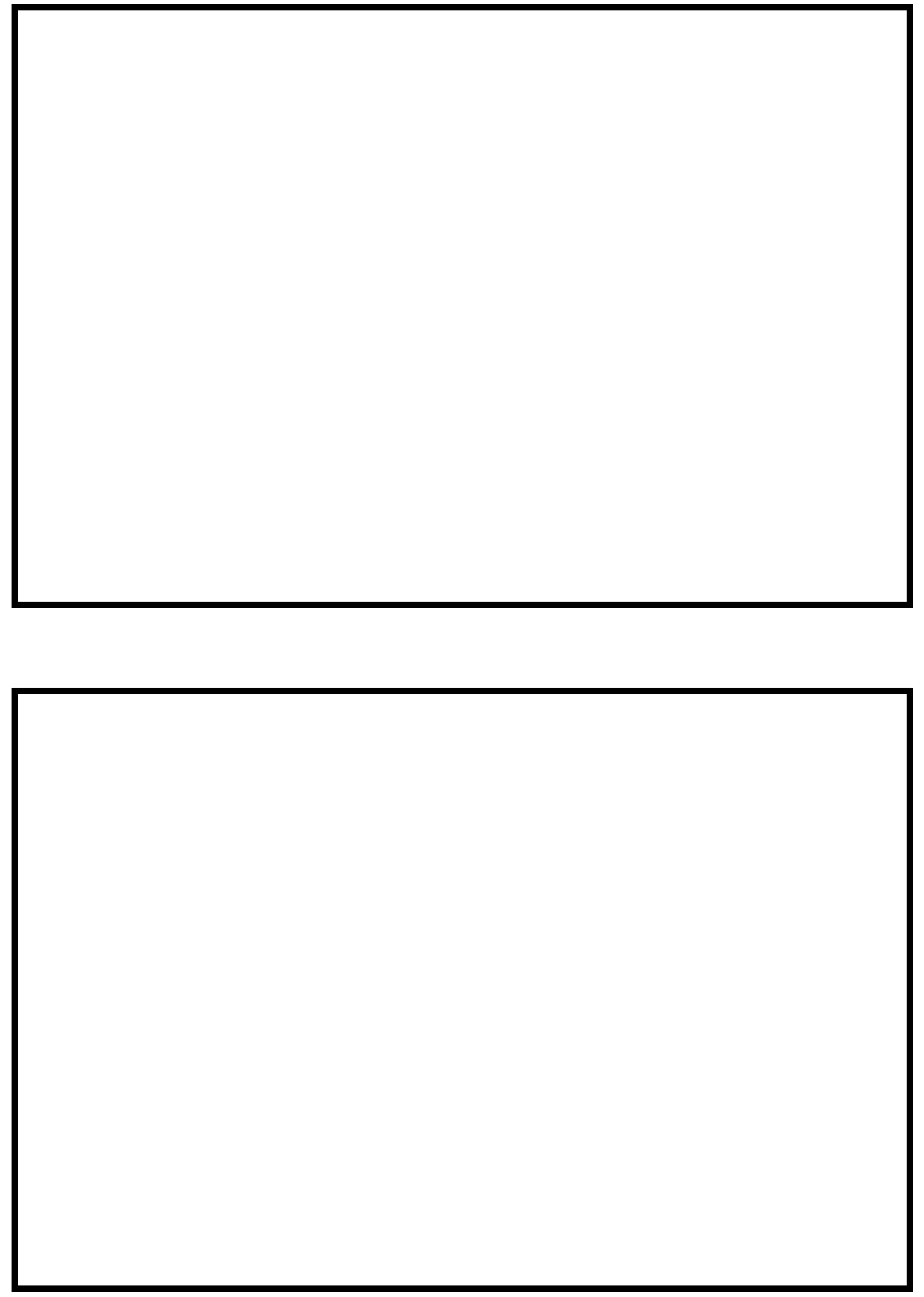


\section{LEVEL II SUMMARY}

\begin{tabular}{llllll} 
Structure Number & WALDTH00450021 & Stream & \multicolumn{2}{c}{ Joes Brook } & \\
& Road & TH 45 & District & R
\end{tabular}

\section{Description of Bridge}

Bridge length $\frac{35}{3} \boldsymbol{f t}$ Bridge width $\frac{15.9}{f t}$ Max span length $\stackrel{29}{ } \boldsymbol{f t}$ Alignment of bridge to road (on curve or straight) Vertical, concrete block Abutment type

Stone fill on abutment? Yes

Embankment type Straight

nomanintin.. af ota... fill

Dato of incnortion Sloping $7 / 27 / 95$ of the right abutment. Type-1, along the base of the left abutment and type-2, along the base

Abutments are "laid-up" concrete blocks.

- . . . . . . . .

\section{No} 0

Is bridge skewed to flood flow according to Yes ' survey?

Angle

There is a moderate channel bend in the upstream reach. Moderate fluvial erosion has deyeloped in the location where the bend impacts the upstream right bank.

Debris accumulation on bridge at time of Level I or Level II site visit:

\begin{tabular}{|c|c|c|c|}
\hline & $\begin{array}{c}\text { Date of insmortion } \\
7 / 27 / 95 \\
\end{array}$ & $\begin{array}{l}\text { Percent of alommol } \\
\text { blocked inortzontatly }\end{array}$ & $\begin{array}{l}\text { Percent of } 0 \text {. } \\
\text { blocked verticatty }\end{array}$ \\
\hline & $8 / 7 / 95$ & 0 & 0 \\
\hline & Low. & & \\
\hline
\end{tabular}

\section{Potential for debris}

None as of 7/27/95. 


\section{Description of the Geomorphic Setting}

General topography The channel is located within a moderate relief valley with a flat to slightly irregular flood plain with steep valley walls on both sides.

Geomorphic conditions at bridge site: downstream (DS), upstream (US)

Date of inspection $\quad 7 / 27 / 95$

DS left: $\quad$ Moderately sloped channel bank to a narrow flood plain.

DS right: Steep channel bank to a narrow flood plain.

US left: $\quad$ Steep channel bank to a narrow flood plain

US right: $\quad$ Narrow flood plain.

\section{Description of the Channel}

$\begin{array}{llll}\text { Average top width } & \text { Average depth } & \frac{5}{\text { Silt / Sand }}\end{array}$

Predominant bed material

Bank material Sinuous but stable

with alluvial channel boundaries and a narrow flood plain.

$7 / 27 / 95$

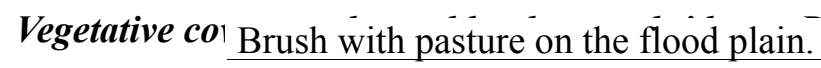

DS left: $\quad$ Trees and brush with pasture on the flood plain.

DS right: Brush with pasture on the flood plain.

US left: $\quad$ Pasture and brush.

US right: $\quad$ Yes

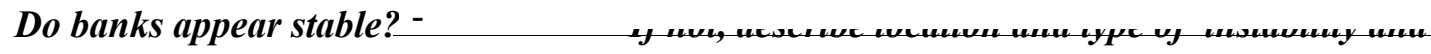

date of observatton.

None, $7 / 27 / 95$.

Describe any obstructions in channel and date of observation. 


\title{
Hydrology
}

Drainage area $\frac{18.7}{m i^{2}}$

Percentage of drainage area in physiographic provinces: (approximate)

Physiographic province/section New England/New England Upland
Percent of drainage area 100

\begin{abstract}
Is drainage area considered rural or urban?
Rural None.

urbanization:-

Describe any significant
\end{abstract}

Is there a USGS gage on the stream of interest?

No

USGS gage description

USGS gage number

Gage drainage area $\mathrm{mi}^{2}$

$--$

$--$

... . . . n . . . . . .

No

Is there a lake/p .

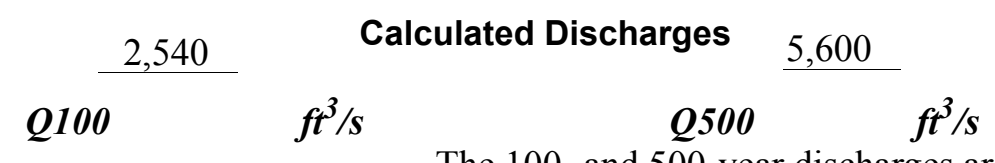

The 100- and 500-year discharges are based on a

drainage area relationship.[(18.7/18.8)exp 0.67] with bridge number 27 over Joes Brook in Cabot. Bridge number 27 has flood frequency estimates available from the VTAOT database.

The drainage area above bridge number 27 is 18.8 square miles. The discharges are within a range defined by several empirical flood frequency curves (Benson, 1962; Johnson and Tasker, 1974; FHWA, 1983; Potter, 1957a\&b; Talbot, 1887). 


\section{Description of the Water-Surface Profile Model (WSPRO) Analysis}

Datum for WSPRO analysis (USGS survey, sea level, VTAOT plans)

USGS survey

Datum tie between USGS survey and VTAOT plans

None.

Description of reference marks used to determine USGS datum. $\quad$ RM1 is a painted high

point on top of ledge on the upstream side of the left road approach, $40 \mathrm{ft}$ from the house (elev.

$504.98 \mathrm{ft}$, arbitrary survey datum). RM2 is a chiseled X on top of the downstream end of the

right abutment (elev. $498.92 \mathrm{ft}$, arbitrary survey datum).

\section{Cross-Sections Used in WSPRO Analysis}

\begin{tabular}{cccl}
\hline ICross-section & $\begin{array}{c}\text { Section } \\
\text { Reference } \\
\text { Distance } \\
\text { (SRD) } \text { in feet }\end{array}$ & $\begin{array}{c}{ }^{2} \text { Cross-section } \\
\text { development }\end{array}$ & \multicolumn{1}{c}{ Comments } \\
\hline EXITX & -46 & 1 & $\begin{array}{l}\text { Exit section } \\
\text { Downstream Full-valley } \\
\text { section (Templated from } \\
\text { EXITX) }\end{array}$ \\
BRIDG & 0 & 2 & $\begin{array}{l}\text { Bridge section } \\
\text { Road Grade section }\end{array}$ \\
RDWAY & 0 & 1 & $\begin{array}{l}\text { Modelled Approach sec- } \\
\text { tion (Templated from } \\
\text { APPRO }\end{array}$ \\
& 10 & 1 & $\begin{array}{l}\text { APTEM) } \\
\text { Approach section as sur- } \\
\text { veyed (Used as a tem- } \\
\text { plate) }\end{array}$ \\
\hline
\end{tabular}

${ }^{1}$ For location of cross-sections see plan-view sketch included with Level I field form, Appendix E.

For more detail on how cross-sections were developed see WSPRO input file. 


\section{Data and Assumptions Used in WSPRO Model}

Hydraulic analyses of the reach were done by use of the Federal Highway Administration's WSPRO step-backwater computer program (Shearman and others, 1986, and Shearman, 1990). The analyses reported herein reflect conditions existing at the site at the time of the study. Furthermore, in the development of the model it was necessary to assume no accumulation of debris or ice at the site. Results of the hydraulic model are presented in the Bridge Hydraulic Summary, Appendix B, and figure 7.

Channel roughness factors (Manning's " $n$ ") used in the hydraulic model were estimated using field inspections at each cross section following the general guidelines described by Arcement and Schneider (1989). Final adjustments to the values were made during the modelling of the reach. Channel " $n$ " values for the reach ranged from 0.045 to 0.064 and overbank " $\mathrm{n}$ " values ranged from 0.045 to 0.050 .

Normal depth at the exit section (EXITX) was assumed as the starting water surface. This depth was computed by use of the slope-conveyance method outlined in the user's manual for WSPRO (Shearman, 1990). The slope used was $0.0092 \mathrm{ft} / \mathrm{ft}$, which was from surveyed points downstream of the bridge.

The approach section (APTEM) was surveyed one bridge length upstream of the upstream face as recommended by Shearman and others (1986). The surveyed approach section (APTEM) was truncated at the top of the right bank by templating. This prevents flow beyond the right high bank into the low lying area, establishing the modelled approach section (APPRO). This location also provides a consistent method for determining scour variables.

For the incipient-overtopping discharge, WSPRO assumes critical depth at the bridge section. A supercritical model was developed for this discharge. After analyzing both the supercritical and subcritical profiles for the discharge, it can be determined that the water surface profile does pass through critical depth within the bridge opening. Thus, the assumption of critical depth at the bridge is a satisfactory solution. 


\section{Bridge Hydraulics Summary}

\begin{tabular}{lll} 
Average bridge embankment elevation & 501.3 \\
\cline { 3 - 3 } Average low steel elevation & 498.8 & $\boldsymbol{f t}$
\end{tabular}

100-year discharge $\quad 2,540 \quad \mathrm{ft}^{3} / \mathrm{s}$

Water-surface elevation in bridge opening $\quad 498.9 \quad f t$

Road overtopping? ___ Yes Discharge over road __ $228 \quad \mathrm{ft}^{3} / \mathrm{s}$

\begin{tabular}{llll} 
Area of flow in bridge opening & $248 \quad \mathrm{ft}^{2}$ \\
\cline { 2 - 3 } Average velocity in bridge opening & 9.3 & $\mathrm{ft} / \mathrm{s}$
\end{tabular}

Maximum WSPRO tube velocity at bridge $11.6 \mathrm{ft} / \mathrm{s}$

Water-surface elevation at Approach section with bridge 500.9

Water-surface elevation at Approach section without bridge $\quad \overline{496.2}$

Amount of backwater caused by bridge

$4.7 \quad i$

500-year discharge $\quad 5,600 \quad \mathrm{ft}^{3} / \mathrm{s}$

Water-surface elevation in bridge opening

$498.9 \boldsymbol{f t}$

Road overtopping? ___ Yes Discharge over road __ 2,740 $\mathrm{ft}^{3} / \mathrm{s}$

Area of flow in bridge opening _ $\quad 248 \quad \mathrm{ft}^{2}$

Average velocity in bridge opening $11.6 \mathrm{ft} / \mathrm{s}$

Maximum WSPRO tube velocity at bridge 14.4 's

Water-surface elevation at Approach section with bridge 502.9

Water-surface elevation at Approach section without bridge $\quad 499.1$

Amount of backwater caused by bridge 3.8 ,t

Incipient overtopping discharge $\quad 2,070 \mathrm{ft}^{3} / \mathrm{s}$

Water-surface elevation in bridge opening $495.2 \quad t$

Area of flow in bridge opening $\quad 152 \quad \mathrm{ft}^{2}$

Average velocity in bridge opening $\quad 13.6 \quad \mathrm{ft} / \mathrm{s}$

Maximum WSPRO tube velocity at bridge $\quad 17.8 \mathrm{ft} / \mathrm{s}$

Water-surface elevation at Approach section with bridge

Water-surface elevation at Approach section without bridge

498.9

Amount of backwater caused by bridge $\quad 3.7_{\text {.t }}^{\text {it }}$

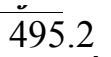




\section{Scour Analysis Summary}

\section{Special Conditions or Assumptions Made in Scour Analysis}

Scour depths were computed using the general guidelines described in Hydraulic Engineering Circular 18 (Richardson and others, 1995). Scour depths were calculated assuming an infinite depth of erosive material and a homogeneous particle-size distribution.

At this site, the 100-year and 500-year discharges resulted in unsubmerged orifice flow. Contraction scour at bridges with orifice flow is best estimated by use of the Chang pressure-flow scour equation (oral communication, J. Sterling Jones, October 4, 1996). Thus, contraction scour for these discharges was computed by use of the Chang equation (Richardson and others, 1995, p. 145-146). Contraction scour for the incipient roadwayovertopping discharge was computed by use of the Laursen clear-water contraction scour equation (Richardson and others, 1995, p. 32, equation 20). The results of the 100-year and 500 -year scour analysis are presented in tables 1 and 2 and a graph of the scour depths is presented in figure 8 . The computed streambed armoring depths suggest that armoring will not limit the depth of contraction scour.

For comparison, contraction scour for the discharges resulting in orifice flow was also computed by use of the Laursen clear-water contraction scour equation and the Umbrell pressure-flow equation (Richardson and others, 1995, p. 144) and presented in Appendix F. Furthermore, for those discharges resulting in unsubmerged orifice flow, contraction scour was computed by substituting estimates for the depth of flow at the downstream bridge face in the contraction scour equations. Results with respect to these substitutions are provided in Appendix F.

Abutment scour was computed by use of the Froehlich equation (Richardson and others, 1995, p. 48, equation 28). Variables for the Froehlich equation include the Froude number of the flow approaching the embankments, the length of the embankment blocking flow, and the depth of flow approaching the embankment less any roadway overtopping. The results of the 100-year and 500-year scour analysis are presented in tables 1 and 2 and a graph of the scour depths is presented in figure 8 . 


\section{Scour Results}

100-yr discharge 500-yr discharge

Contraction scour:

(Scour depths in feet)

Main channel

Live-bed scour

Clear-water scour

Depth to armoring

Left overbank

Right overbank

Local scour:

Abutment scour

Left abutment

14.1

16.4

12.4

19.3-

24.4-

17.9-

Right abutment

Pier scour

Pier 1

Pier 2

Pier 3

Abutments:

Left abutment

Right abutment

Piers:

Pier 1

Pier 2

\section{Riprap Sizing}

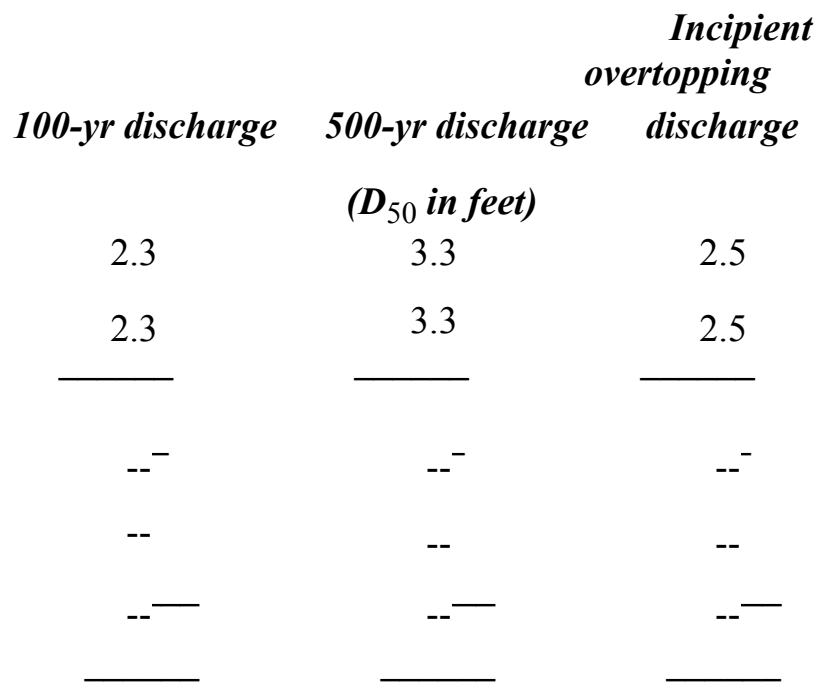




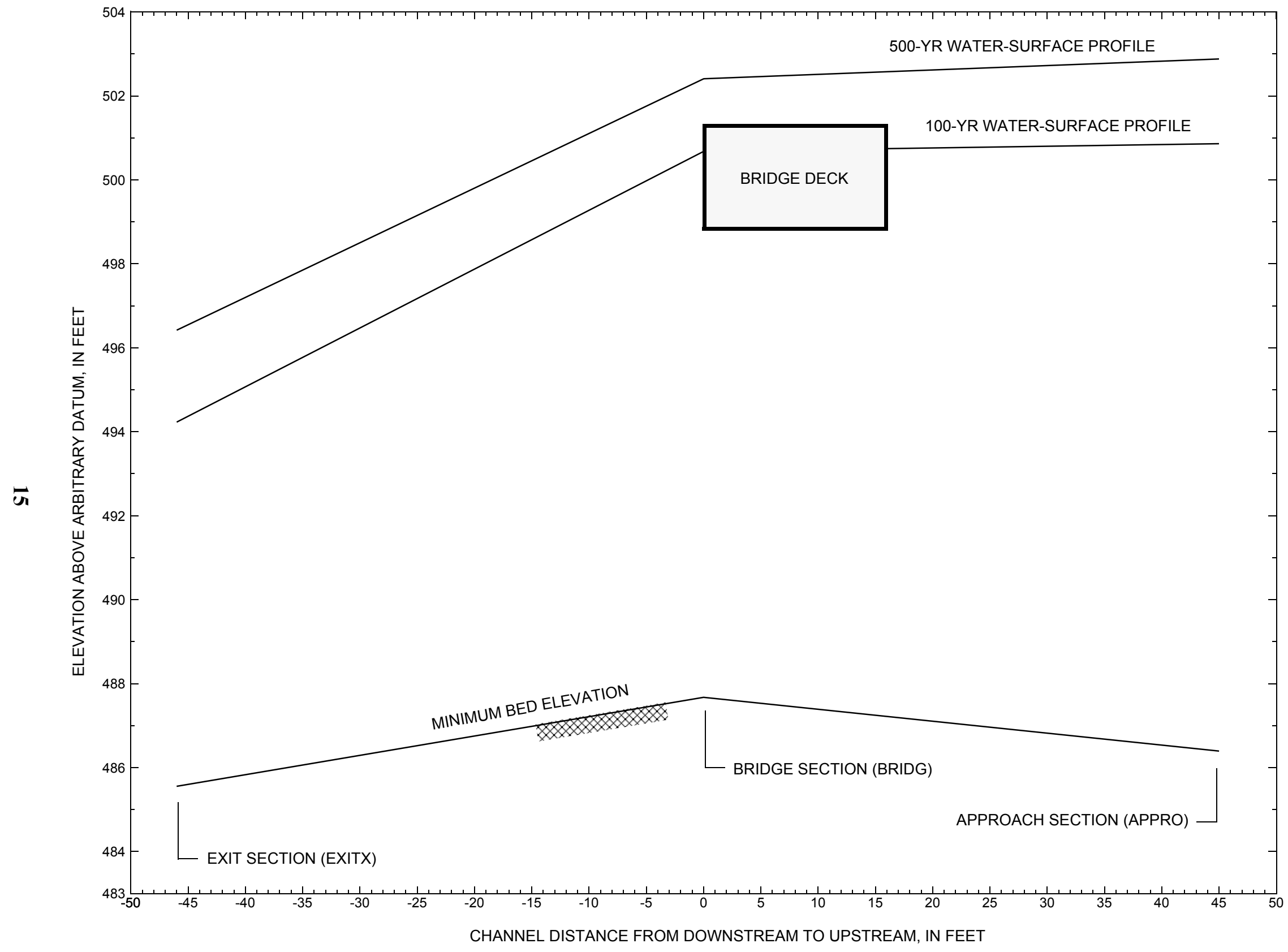

Figure 7. Water-surface profiles for the 100-year and 500-year discharges at structure WALDTH00450021 on Town Highway 45, crossing Joes Brook, Walden, Vermont. 


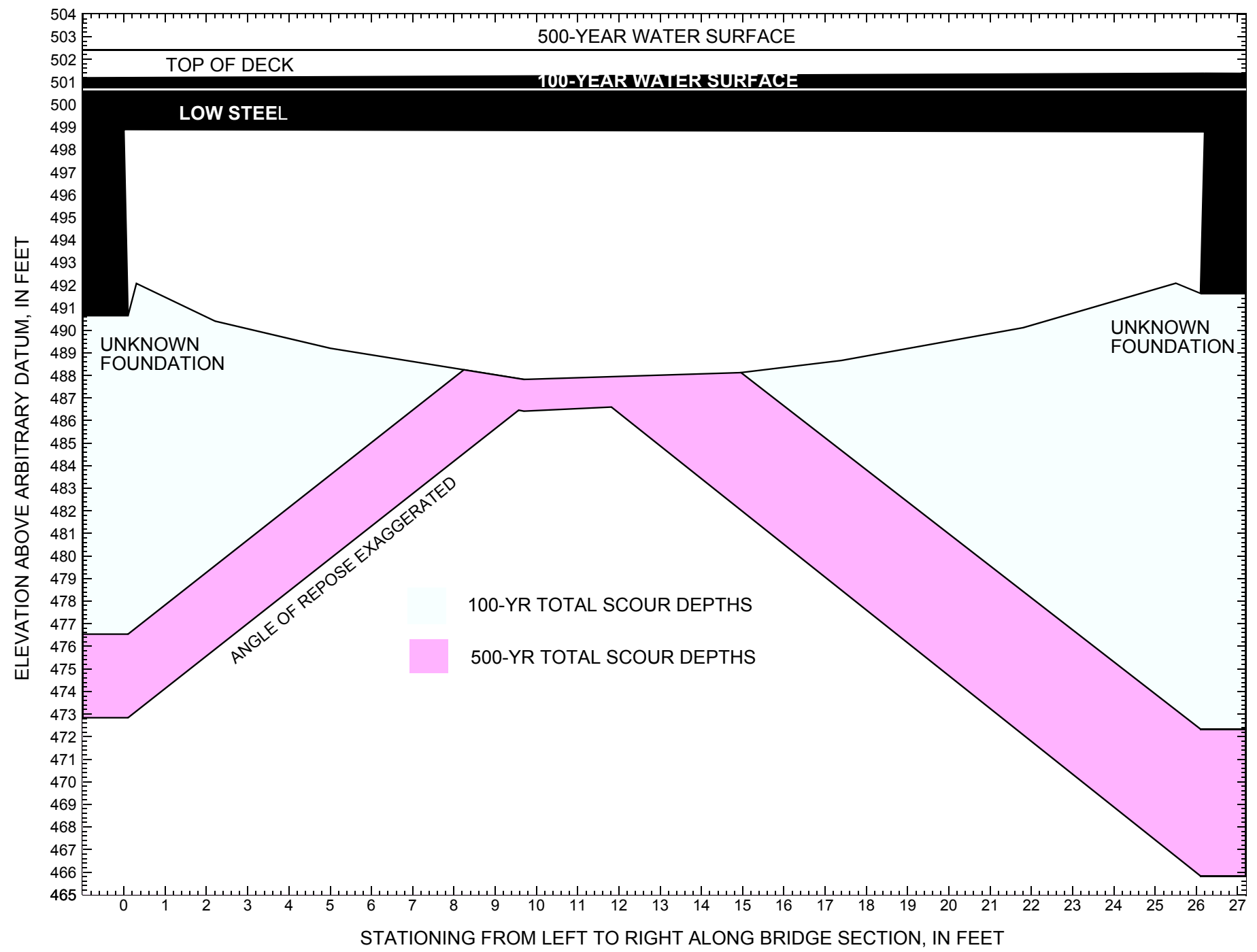

Figure 8. Scour elevations for the 100-year and 500-year discharges at structure WALDTH00450021 on Town Highway 45, crossing Joes Brook, Walden, Vermont. 


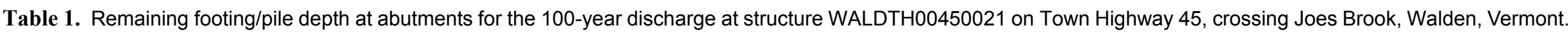
[VTAOT, Vermont Agency of Transportation; --,no data]

\begin{tabular}{|c|c|c|c|c|c|c|c|c|c|c|c|}
\hline Description & Station $^{1}$ & $\begin{array}{l}\text { VTAOT } \\
\text { minimum } \\
\text { low-chord } \\
\text { elevation } \\
\text { (feet) }\end{array}$ & $\begin{array}{l}\text { Surveyed } \\
\text { minimum } \\
\text { low-chord } \\
\text { elevation } \\
\text { (feet) }\end{array}$ & $\begin{array}{c}\text { Bottom of } \\
\text { footing/pile } \\
\text { elevation }{ }^{2} \\
\text { (feet) }\end{array}$ & $\begin{array}{c}\text { Channel } \\
\text { elevation at } \\
\text { abutment/ } \\
\text { pier }^{2} \\
\text { (feet) }\end{array}$ & $\begin{array}{l}\text { Contraction } \\
\text { scour depth } \\
\text { (feet) }\end{array}$ & $\begin{array}{l}\text { Abutment } \\
\text { scour } \\
\text { depth } \\
\text { (feet) }\end{array}$ & $\begin{array}{l}\text { Pier } \\
\text { scour } \\
\text { depth } \\
\text { (feet) }\end{array}$ & $\begin{array}{l}\text { Depth of } \\
\text { total scour } \\
\text { (feet) }\end{array}$ & $\begin{array}{c}\text { Elevation of } \\
\text { scour }^{2} \\
\text { (feet) }\end{array}$ & $\begin{array}{c}\text { Remaining } \\
\text { footing/pile } \\
\text { depth } \\
\text { (feet) }\end{array}$ \\
\hline \multicolumn{12}{|c|}{100 -yr. discharge is 2,540 cubic-feet per second } \\
\hline Left abutment & 0.0 & -- & 498.9 & -- & 490.6 & 0.0 & 14.1 & -- & 14.1 & 476.5 & -- \\
\hline Right abutment & 26.2 & -- & 498.8 & -- & 491.6 & 0.0 & 19.3 & -- & 19.3 & 472.3 & -- \\
\hline
\end{tabular}

1.Measured along the face of the most constricting side of the bridge.

2.Arbitrary datum for this study.

Table 2. Remaining footing/pile depth at abutments for the 500-year discharge at structure WALDTH00450021 on Town Highway 45, crossing Joes Brook, Walden, Vermont. [VTAOT, Vermont Agency of Transportation; --, no data]

\begin{tabular}{|c|c|c|c|c|c|c|c|c|c|c|c|}
\hline Description & Station $^{1}$ & $\begin{array}{l}\text { VTAOT } \\
\text { minimum } \\
\text { low-chord } \\
\text { elevation } \\
\text { (feet) }\end{array}$ & $\begin{array}{l}\text { Surveyed } \\
\text { minimum } \\
\text { low-chord } \\
\text { elevation } \\
\text { (feet) }\end{array}$ & $\begin{array}{c}\text { Bottom of } \\
\text { footing/pile } \\
\text { elevation }{ }^{2} \\
\text { (feet) }\end{array}$ & $\begin{array}{c}\text { Channel } \\
\text { elevation at } \\
\text { abutment/ } \\
\text { pier }^{2} \\
\text { (feet) }\end{array}$ & $\begin{array}{l}\text { Contraction } \\
\text { scour depth } \\
\text { (feet) }\end{array}$ & $\begin{array}{l}\text { Abutment } \\
\text { scour } \\
\text { depth } \\
\text { (feet) }\end{array}$ & $\begin{array}{l}\text { Pier } \\
\text { scour } \\
\text { depth } \\
\text { (feet) }\end{array}$ & $\begin{array}{l}\text { Depth of } \\
\text { total scour } \\
\text { (feet) }\end{array}$ & $\begin{array}{c}\text { Elevation of } \\
\text { scour }^{2} \\
\text { (feet) }\end{array}$ & $\begin{array}{c}\text { Remaining } \\
\text { footing/pile } \\
\text { depth } \\
\text { (feet) }\end{array}$ \\
\hline \multicolumn{12}{|c|}{500 -yr. discharge is 5,600 cubic-feet per second } \\
\hline Left abutment & 0.0 & -- & 498.9 & -- & 490.6 & 1.4 & 16.4 & -- & 17.8 & 472.8 & -- \\
\hline Right abutment & 26.2 & -- & 498.8 & -- & 491.6 & 1.4 & 24.4 & -- & 25.8 & 465.8 & -- \\
\hline
\end{tabular}

1.Measured along the face of the most constricting side of the bridge.

2.Arbitrary datum for this study. 


\section{SELECTED REFERENCES}

Arcement, G.J., Jr., and Schneider, V.R., 1989, Guide for selecting Manning's roughness coefficients for natural channels and flood plains: U.S. Geological Survey Water-Supply Paper 2339, 38 p.

Barnes, H.H., Jr., 1967, Roughness characteristics of natural channels: U.S. Geological Survey Water-Supply Paper 1849,213 p.

Benson, M. A., 1962, Factors Influencing the Occurrence of Floods in a Humid Region of Diverse Terrain: U.S. Geological Survey WaterSupply Paper 1580-B, 64 p.

Brown, S.A. and Clyde, E.S., 1989, Design of riprap revetment: Federal Highway Administration Hydraulic Engineering Circular No. 11, Publication FHWA-IP-89-016, 156 p.

Federal Highway Administration, 1983, Runoff estimates for small watersheds and development of sound design: Federal Highway Administration Report FHWA-RD-77-158.

Federal Highway Administration, 1993, Stream Stability and Scour at Highway Bridges: Participant Workbook: Federal Highway Administration Report FHWA-HI-91-011.

Froehlich, D.C., 1989, Local scour at bridge abutments in Ports, M.A., ed., Hydraulic Engineering--Proceedings of the 1989 National Conference on Hydraulic Engineering: New York, American Society of Civil Engineers, p. 13-18.

Hayes, D.C.,1993, Site selection and collection of bridge-scour data in Delaware, Maryland, and Virginia: U.S. Geological Survey WaterResources Investigation Report 93-4017, 23 p.

Interagency Advisory Committee on Water Data, 1982, Guidelines for determining flood flow frequency: U.S. Geological Survey, Bulletin 17B of the Hydrology Subcommittee, 190 p.

Johnson, C.G. and Tasker, G.D.,1974, Progress report on flood magnitude and frequency of Vermont streams: U.S. Geological Survey OpenFile Report 74-130, 37 p.

Lagasse, P.F., Schall, J.D., Johnson, F., Richardson, E.V., Chang, F., 1995, Stream Stability at Highway Structures: Federal Highway Administration Hydraulic Engineering Circular No. 20, Publication FHWA-IP-90-014, 144 p.

Laursen, E.M., 1960, Scour at bridge crossings: Journal of the Hydraulics Division, American Society of Civil Engineers, v. 86, no. HY2, p. 39-53.

Potter, W. D., 1957a, Peak rates of runoff in the Adirondack, White Mountains, and Maine woods area, Bureau of Public Roads

Potter, W. D., 1957b, Peak rates of runoff in the New England Hill and Lowland area, Bureau of Public Roads

Richardson, E.V. and Davis, S.R., 1995, Evaluating scour at bridges: Federal Highway Administration Hydraulic Engineering Circular No. 18, Publication FHWA-IP-90-017, 204 p.

Richardson, E.V., Simons, D.B., and Julien, P.Y., 1990, Highways in the river environment: Federal Highway Administration Publication FHWA-HI-90-016.

Ritter, D.F., 1984, Process Geomorphology: W.C. Brown Co., Debuque, Iowa, 603 p.

Shearman, J.O., 1990, User's manual for WSPRO--a computer model for water surface profile computations: Federal Highway Administration Publication FHWA-IP-89-027, 187 p.

Shearman, J.O., Kirby, W.H., Schneider, V.R., and Flippo, H.N., 1986, Bridge waterways analysis model; research report: Federal Highway Administration Publication FHWA-RD-86-108, 112 p.

Talbot, A.N., 1887, The determination of water-way for bridges and culverts.

U.S. Department of Transportation, 1993, Stream stability and scour at highway bridges, Participant Workbook: Federal Highway Administration Publication FHWA HI-91-011.

U.S. Geological Survey, 1983, St. Johnsbury, Vermont 7.5 X 15 Minute Series quadrangle map: U.S. Geological Survey Topographic Maps, Scale 1:25,000. 


\section{APPENDIX A: \\ WSPRO INPUT FILE}




\section{WSPRO INPUT FILE}

GR

GR

GR

GR

GR

GR

GR

GR

GR

$\mathrm{N}$

SA

*

XS

*

BR

GR

GR

GR

GR

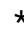

$\mathrm{CD}$

$\mathrm{N}$

*

*

$\mathrm{XR}$

GR

GR

GR

GR

GR

GR

* GR

$\mathrm{XT}$

GR

GR

GR

GR

GR

GR

GR

GR

GT

U.S. Geological Survey WSPRO Input File wald021.wsp Hydraulic analysis for structure WALDTH00450021 Date: 21-APR-97 Bridge 21 on Town Highway 45 over Joes Brook in Walden, VT by MAI

$62930 \quad 552553551516 \quad 17 \quad 13 \quad 3 * \begin{array}{llllllllll}15 & 14 & 23 & 21 & 11 & 12 & 4 & 7 & 3\end{array}$

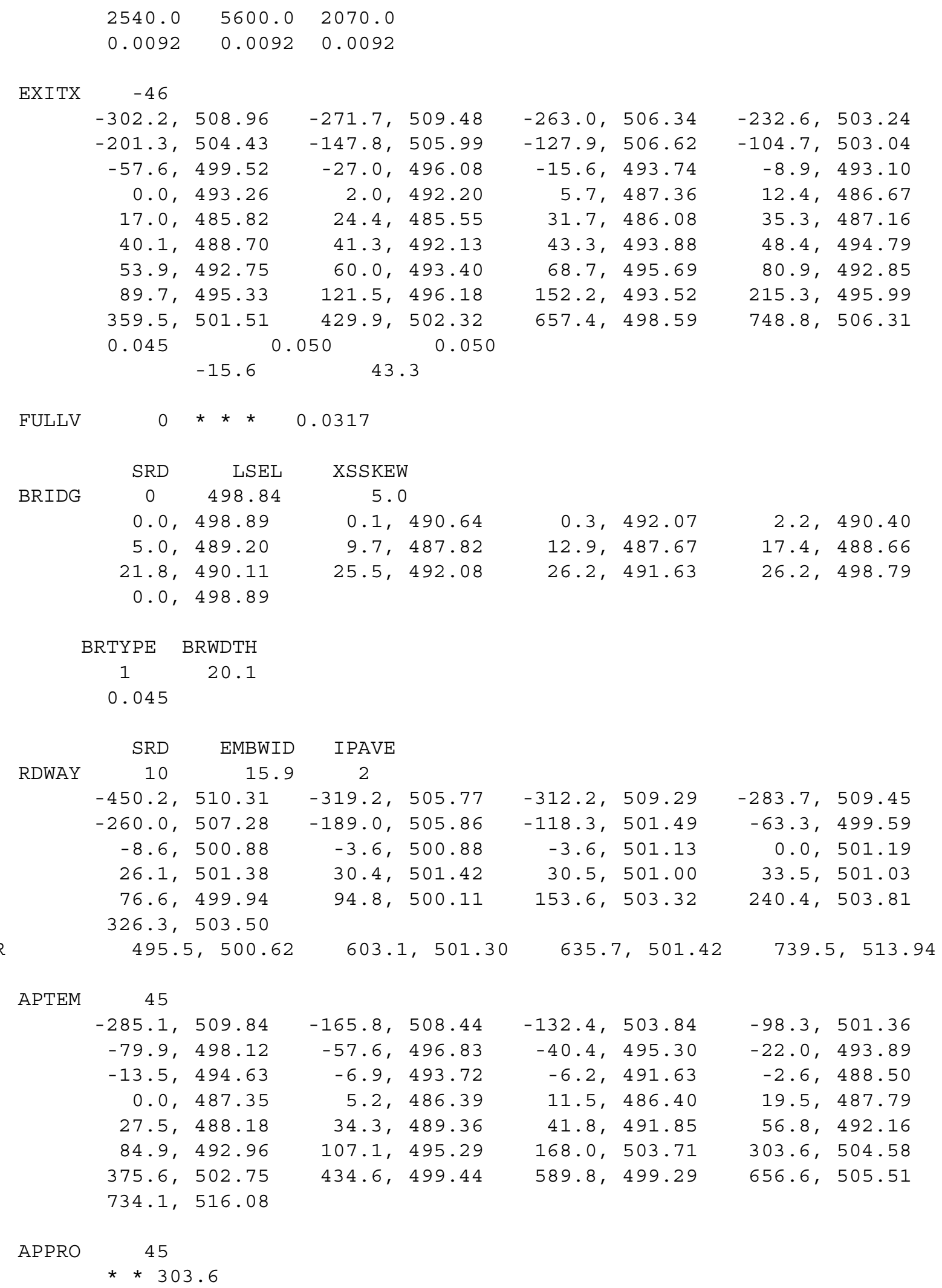


WSPRO INPUT FILE (continued)

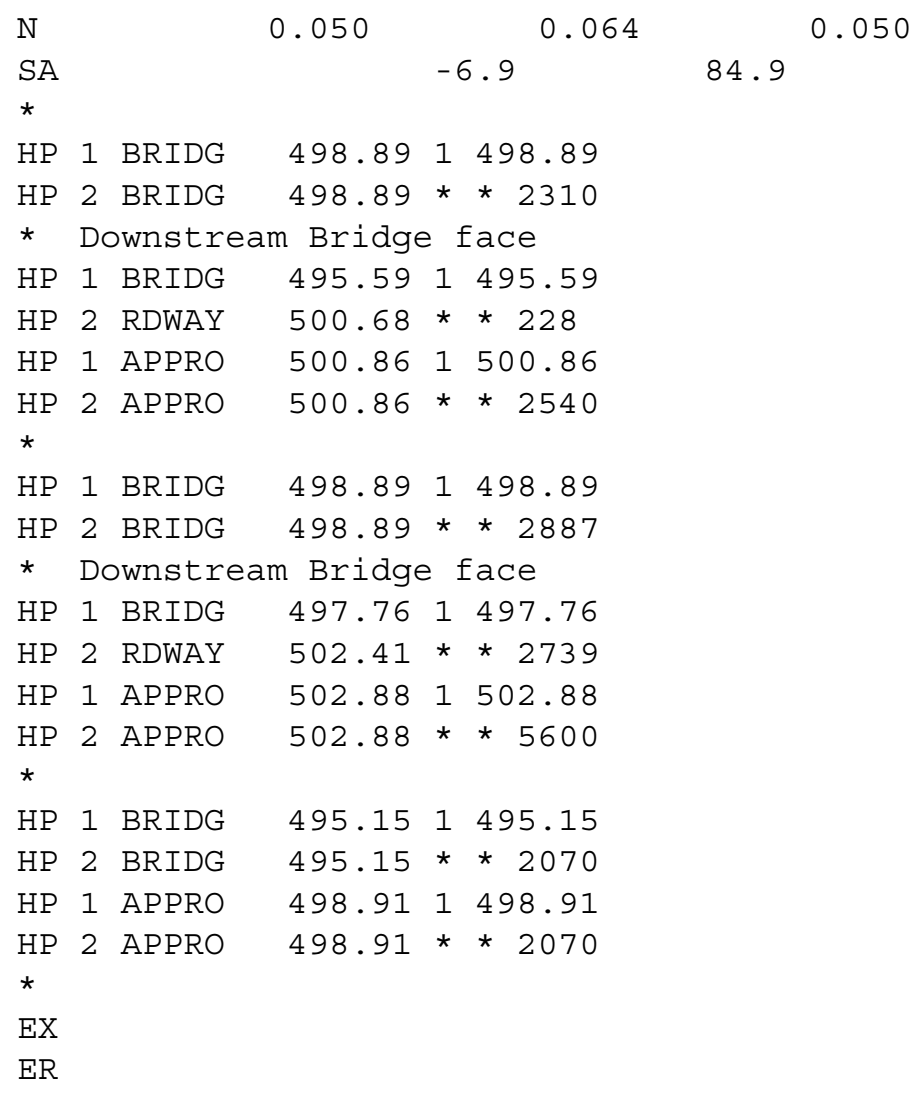




\section{APPENDIX B: \\ WSPRO OUTPUT FILE}




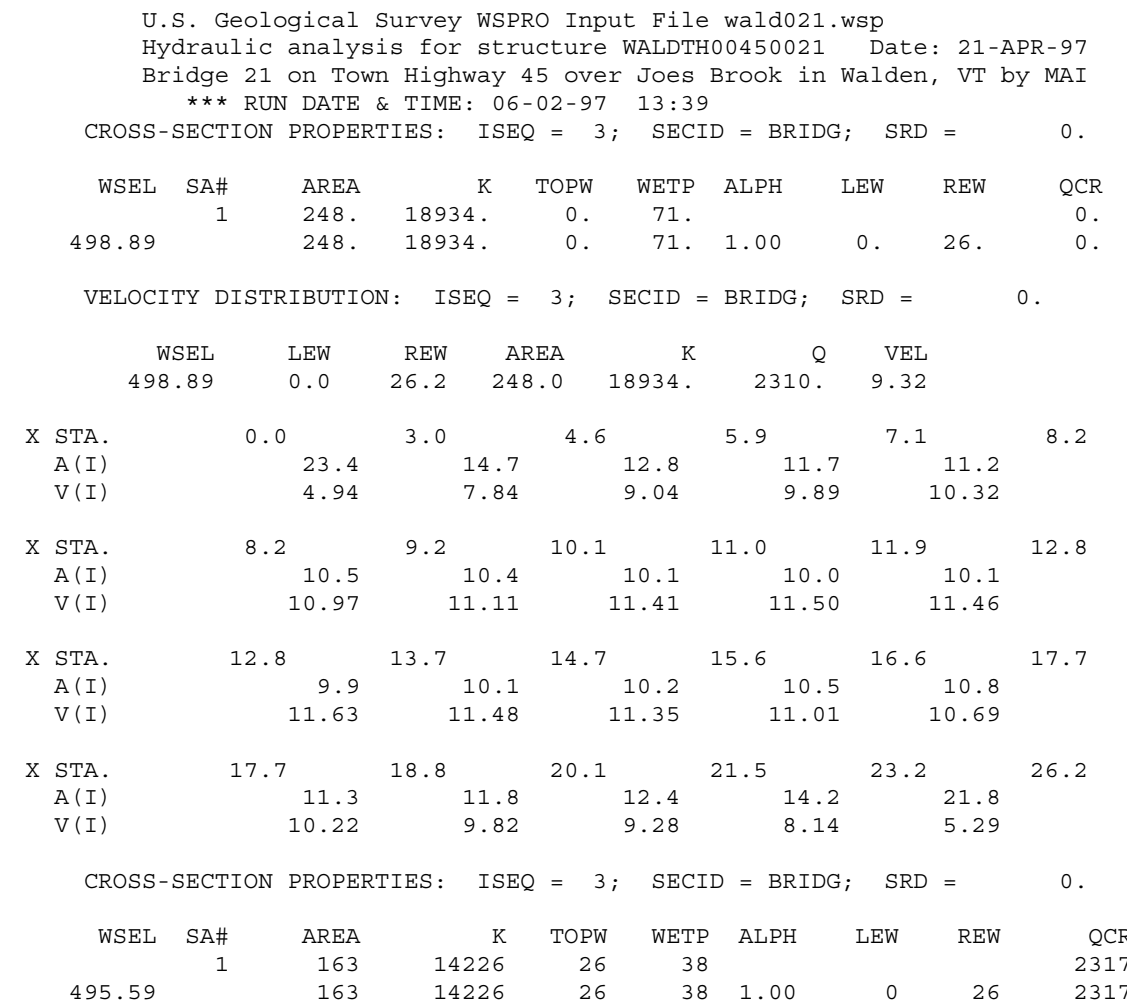

VELOCITY DISTRIBUTION $:$ ISEQ $=4 ; \quad \operatorname{SECID}=$ RDWAY $; \quad \operatorname{SRD}=10$.

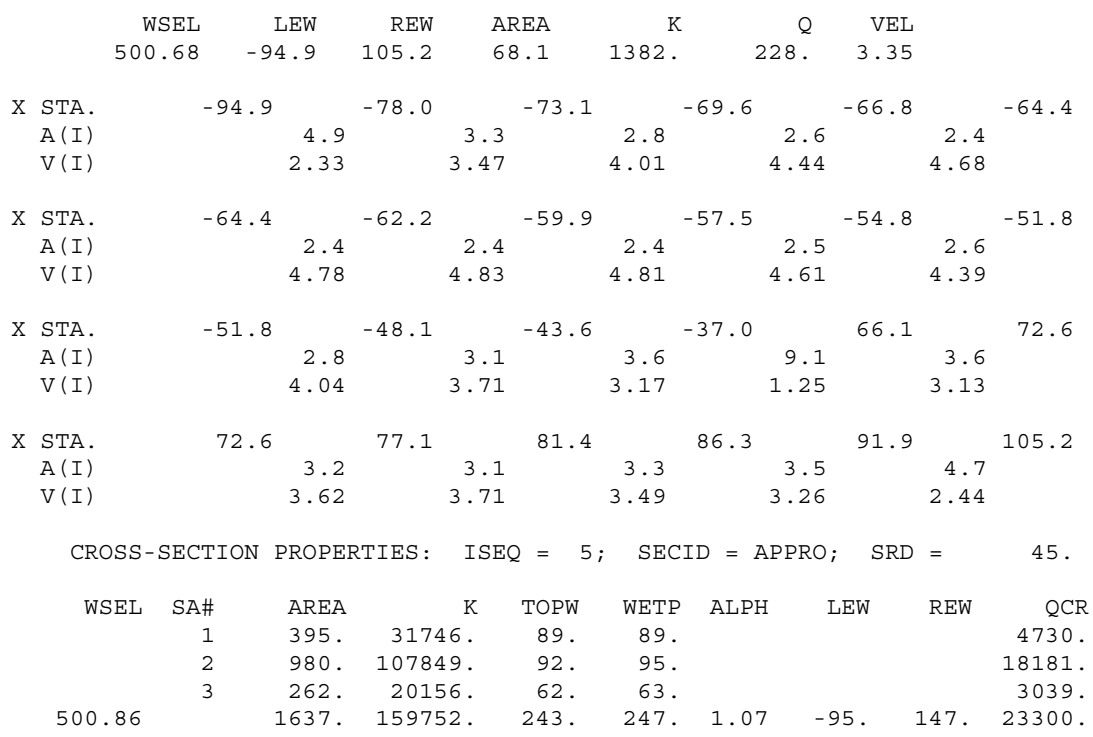

VELOCITY DISTRIBUTION: ISEQ $=5 ; \operatorname{SECID~}=$ APPRO $; \quad \operatorname{SRD}=$

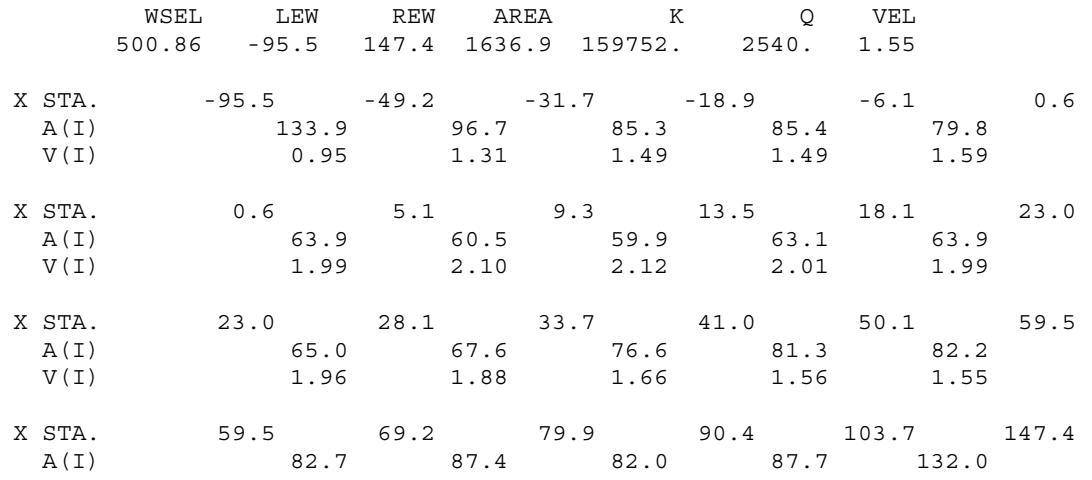


WSPRO OUTPUT FILE (continued)

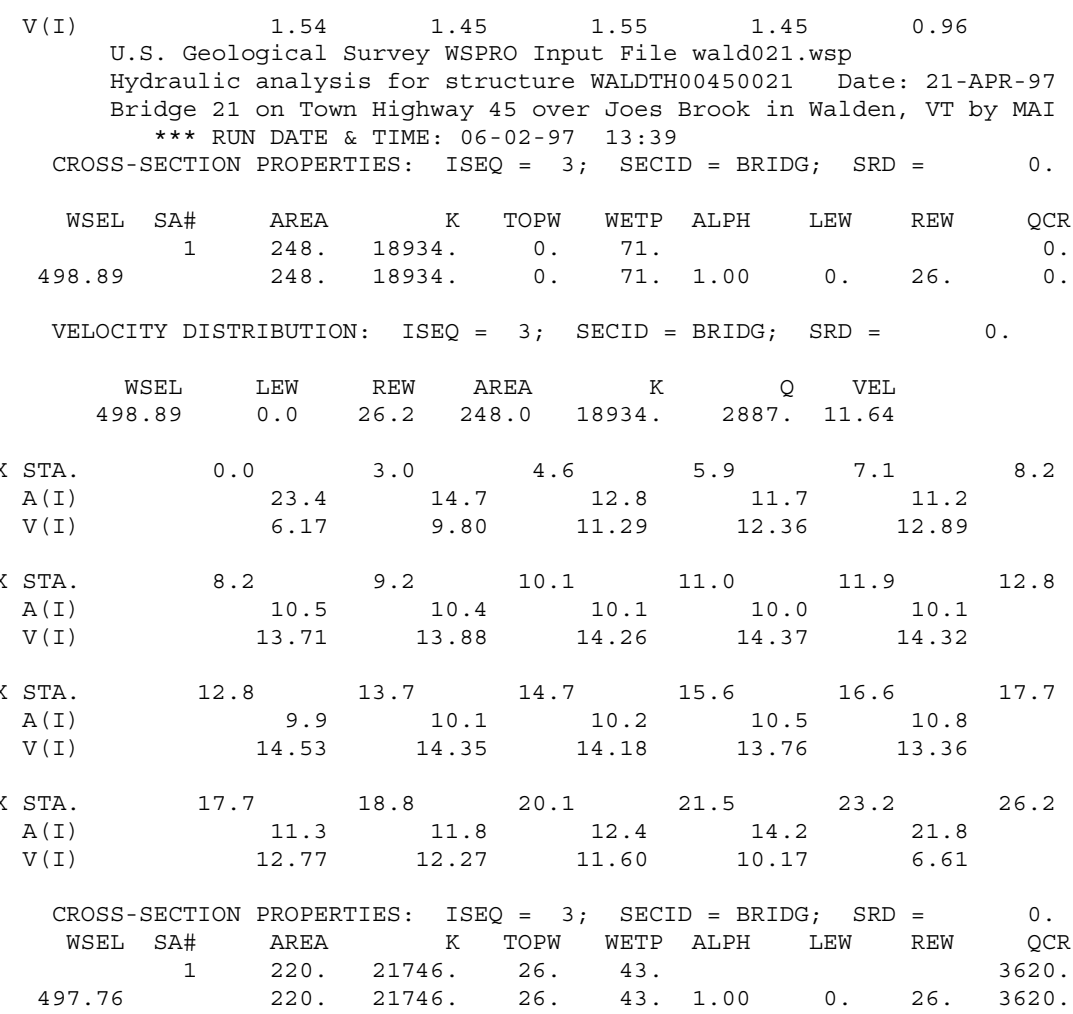

VELOCITY DISTRIBUTION: ISEQ $=4 ; \operatorname{SECID}=$ RDWAY $; \quad \operatorname{SRD}=10$.

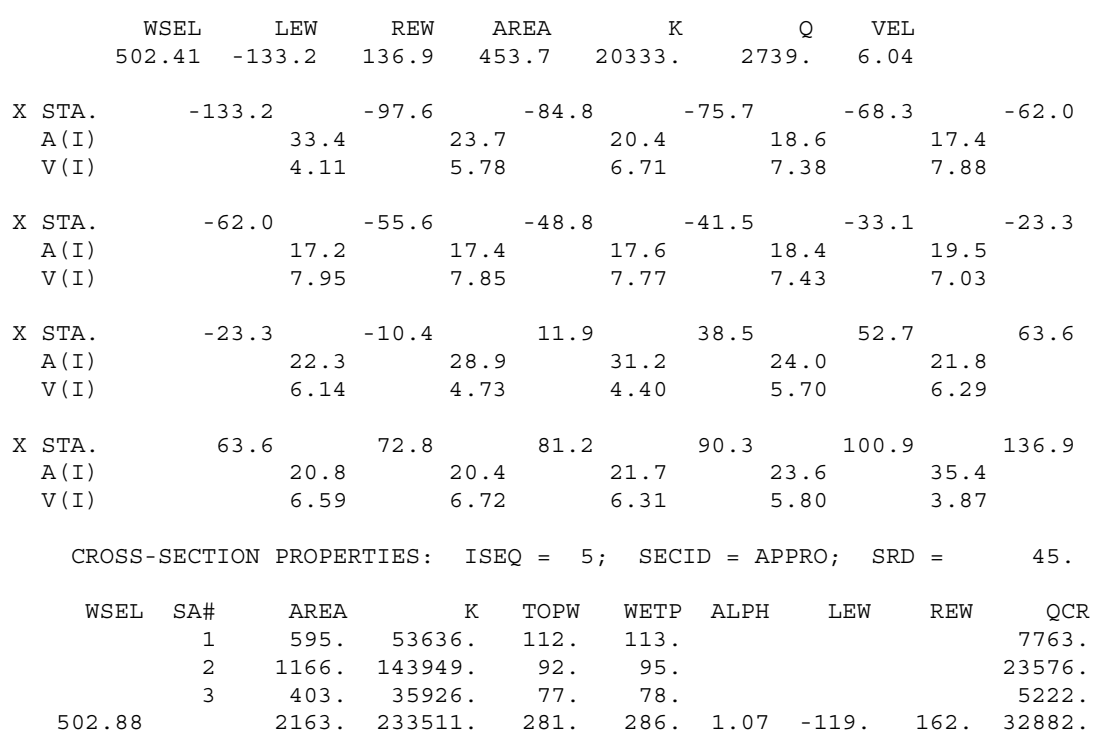

VELOCITY DISTRIBUTION: ISEQ $=5 ; \operatorname{SECID}=\operatorname{APPRO} ; \quad \operatorname{SRD}=45$.

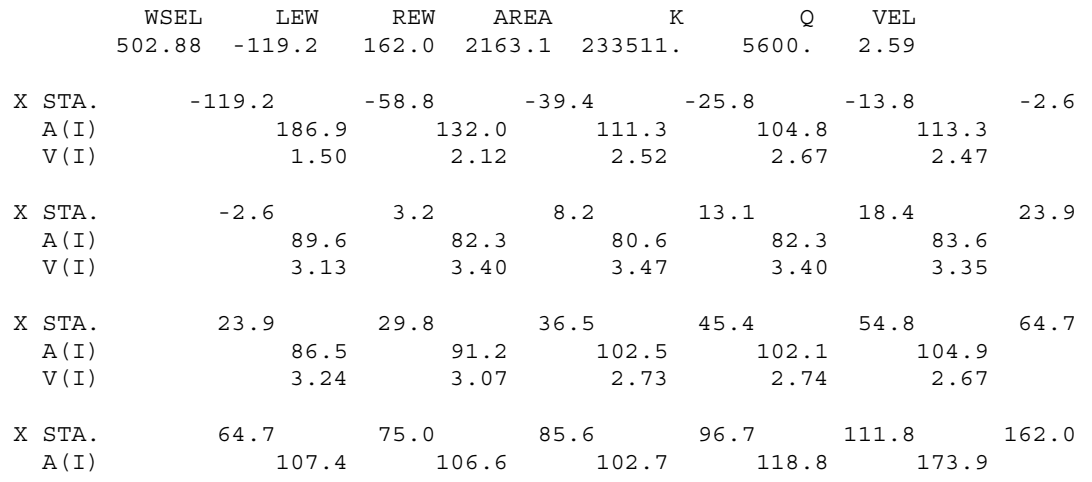


WSPRO OUTPUT FILE (continued)

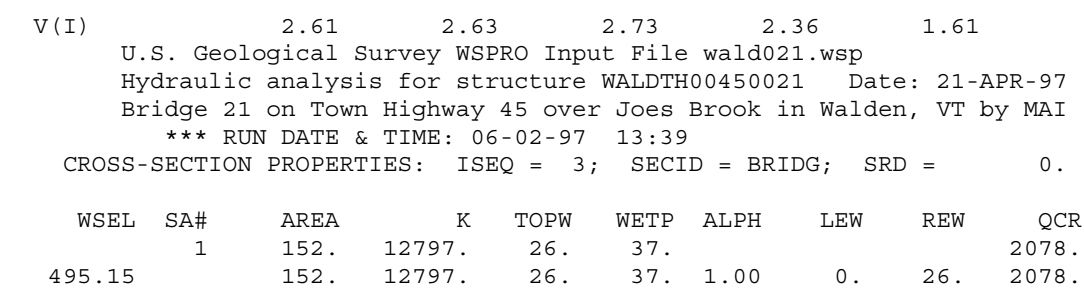

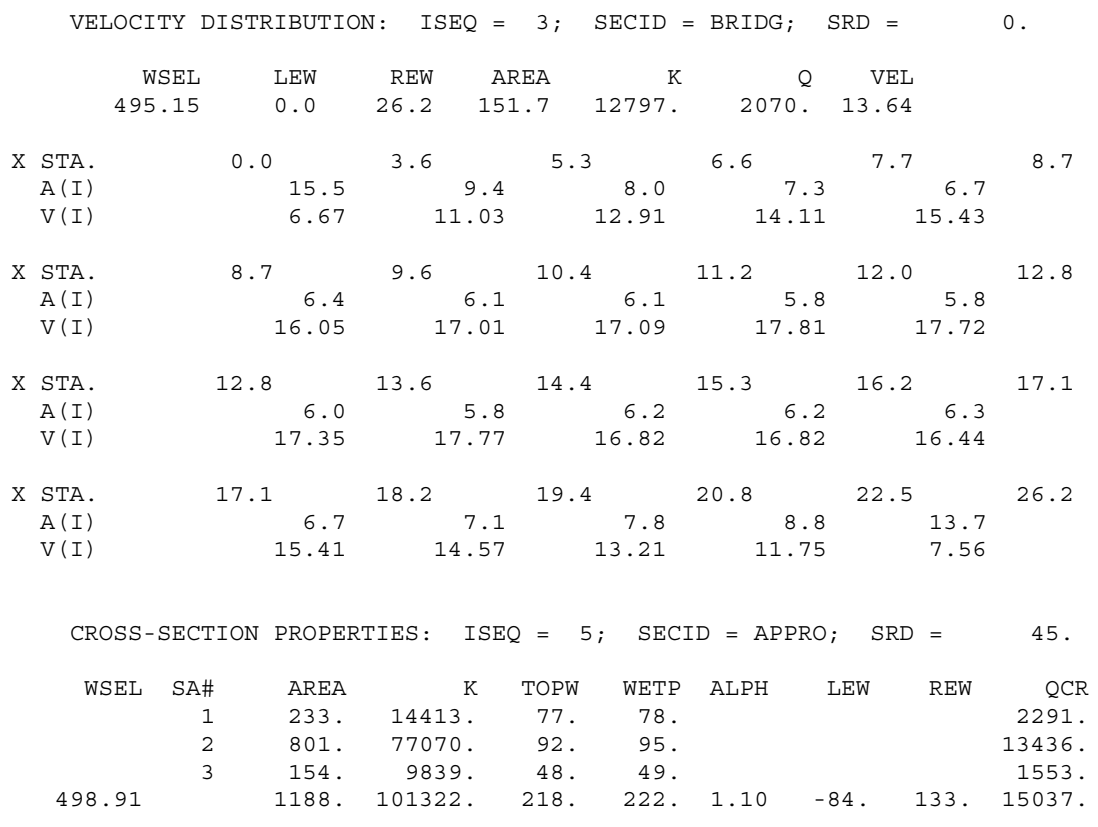

\begin{tabular}{|c|c|c|c|c|c|c|c|c|c|c|c|}
\hline \multirow{3}{*}{\multicolumn{2}{|c|}{$\mathrm{VE}$}} & OCITY I & \multicolumn{3}{|l|}{ DISTRIB } & $5 ;$ & SECID & $=\mathrm{APPRO} ;$ & $\mathrm{SRD}=$ & \multicolumn{2}{|c|}{45.} \\
\hline & & WSEL & LEW & REW & & REA & K & Q & VEL & & \\
\hline & & 498.91 & -84.4 & 133.3 & 1187 & 7.9 & 101322 . & 2070 . & 1.74 & & \\
\hline $\mathrm{X}$ & STA. & & -84.4 & -34.3 & & -19.2 & & -4.8 & 0.5 & & 4.3 \\
\hline & $A(I)$ & & 106.3 & & 69.6 & & 72.0 & 55.6 & & 45.4 & \\
\hline & $V(I)$ & & 0.97 & & 1.49 & & 1.44 & 1.86 & & 2.28 & \\
\hline $\mathrm{x}$ & STA. & & 4.3 & 7.7 & & 11.1 & & 14.7 & 18.5 & & 22.5 \\
\hline & $A(I)$ & & 42.7 & & 42.0 & & 44.0 & 44.4 & & 45.1 & \\
\hline & $V(I)$ & & 2.42 & & 2.46 & & 2.35 & 2.33 & & 2.30 & \\
\hline $\mathrm{x}$ & STA. & & 22.5 & 26.9 & & 31.5 & & 37.1 & 44.9 & & 54.1 \\
\hline & $A(I)$ & & 47.2 & & 48.2 & & 52.5 & 59.2 & & 62.9 & \\
\hline & $V(I)$ & & 2.19 & & 2.15 & & 1.97 & 1.75 & & 1.65 & \\
\hline $\mathrm{x}$ & STA. & & 54.1 & 63.5 & & 73.4 & & 84.3 & 96.1 & & 133.3 \\
\hline & $A(I)$ & & 63.2 & & 63.8 & & 66.5 & 63.5 & & 93.7 & \\
\hline & $V(I)$ & & 1.64 & & 1.62 & & 1.56 & 1.63 & & 1.11 & \\
\hline
\end{tabular}


WSPRO OUTPUT FILE (continued)

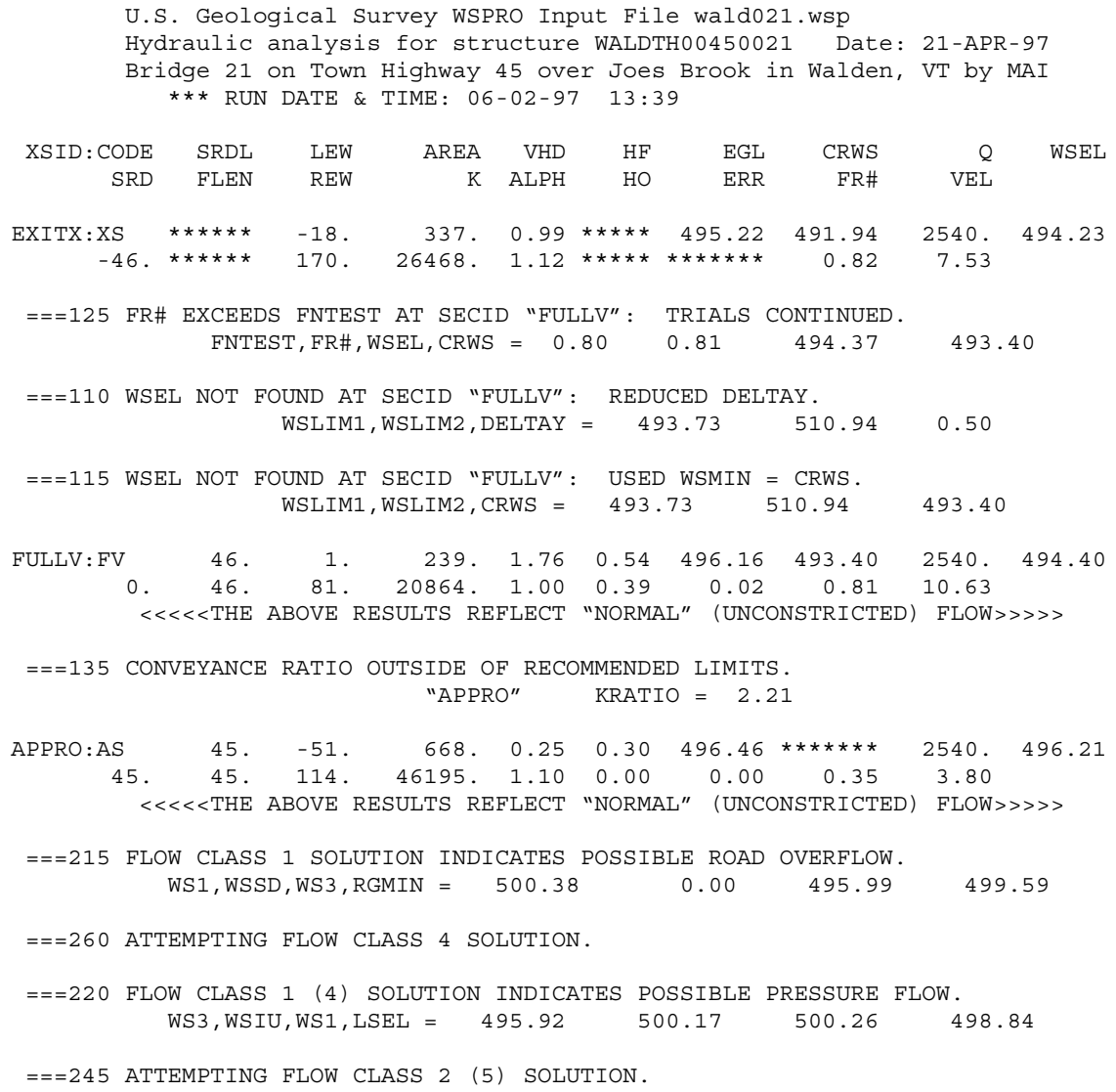

FIRST USER DEFINED TABLE.

$\begin{array}{lrrrrrrrr}\text { XSID : CODE } & \text { SRD } & \text { LEW } & \text { REW } & Q & \text { K } & \text { AREA } & \text { VEL } & \text { WSEL } \\ \text { EXITX : XS } & -46 . & -18 . & 170 . & 2540 . & 26468 . & 337 . & 7.53 & 494.23 \\ \text { FULLV : FV } & 0 . & 1 . & 81 . & 2540 . & 20864 . & 239 . & 10.63 & 494.40 \\ \text { BRIDG : BR } & 0 . & 0 . & 26 . & 2310 . & 18934 . & 248 . & 9.32 & 498.89 \\ \text { RDWAY : RG } & 10 . * * * * * * & 142 . & 228 . * * * * * * * & 0 . & 2.00 & 500.68 \\ \text { APPRO : AS } & 45 . & -95 . & 147 . & 2540 . & 159762 . & 1637 . & 1.55 & 500.86\end{array}$

SECOND USER DEFINED TABLE.

$\begin{array}{lcrrrrrrrr}\text { XSID }: \text { CODE } & \text { CRWS } & \text { FR\# } & \text { YMIN } & \text { YMAX } & \text { HF } & \text { HO } & \text { VHD } & \text { EGL } & \text { WSEL } \\ \text { EXITX:XS } & 491.94 & 0.82 & 485.55 & 509.48 * * * * * * * * * * & 0.99 & 495.22 & 494.23 \\ \text { FULLV : FV } & 493.40 & 0.81 & 487.01 & 510.94 & 0.54 & 0.39 & 1.76 & 496.16 & 494.40 \\ \text { BRIDG : BR } & 495.59 & 0.53 & 487.67 & 498.89 * * * * * * * * * * & 1.35 & 500.24 & 498.89 \\ \text { RDWAY : RG } & * * * * * * * * * * * * * * * & 499.59 & 510.31 & 0.01 * * * * * * & 0.04 & 500.89 & 500.68 \\ \text { APPRO :AS } & 493.06 & 0.11 & 486.39 & 516.08 & 0.06 & 0.54 & 0.04 & 500.90 & 500.86\end{array}$


WSPRO OUTPUT FILE (continued)

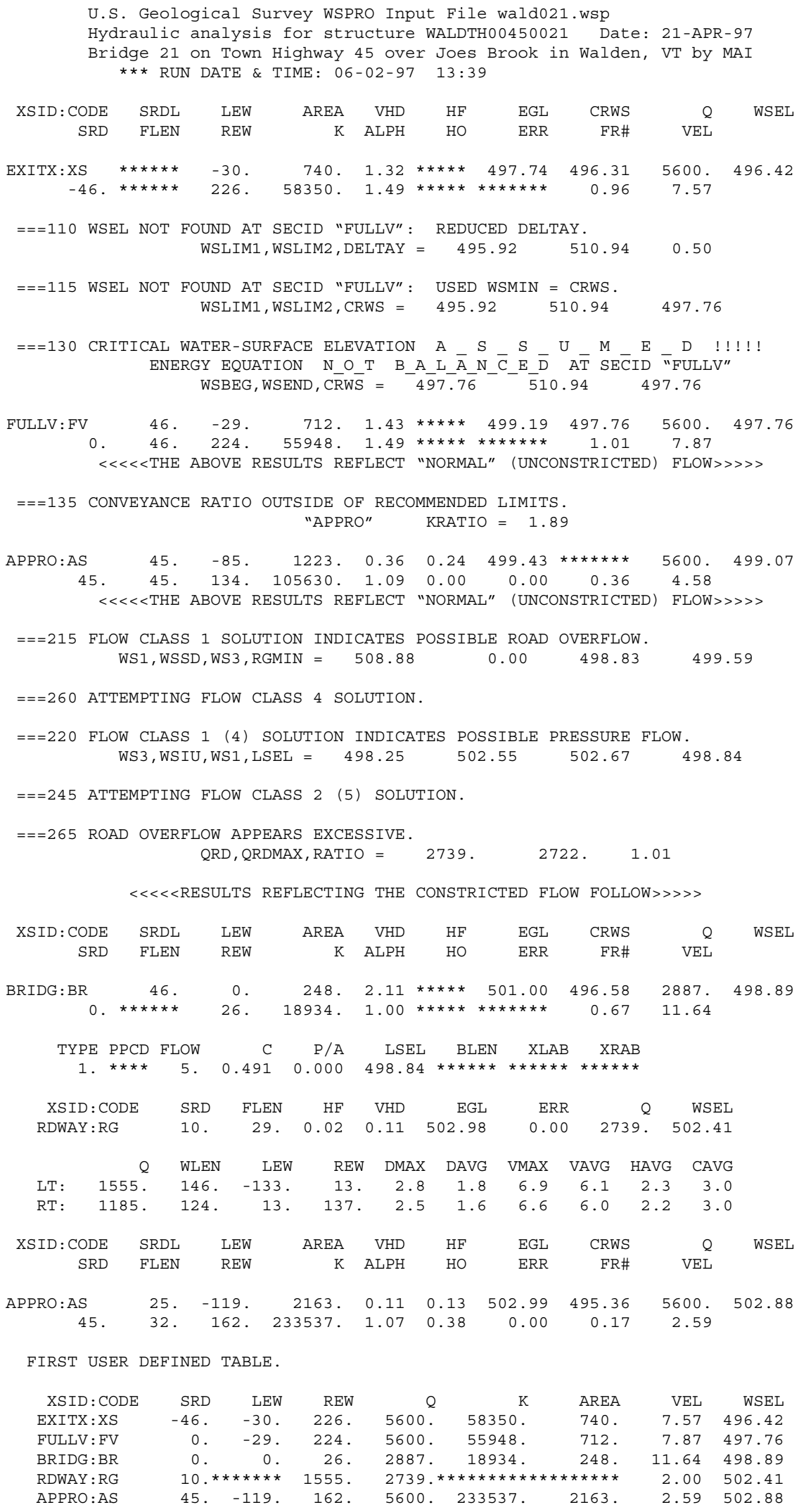

SECOND USER DEFINED TABLE.

\begin{tabular}{|c|c|c|c|c|c|c|c|c|}
\hline XSID: CODE & CRWS & FR\# & YMIN & YMAX & $\mathrm{HF}$ & VHD & EGL & WSEL \\
\hline EXITX:XS & 496.31 & 0.96 & 485.55 & 509.48 * & 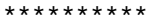 & 1.32 & 497.74 & 496. \\
\hline FULLV : FV & 497.76 & 1.01 & 487.01 & 510.94 * & 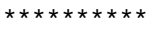 & 1.43 & 499.19 & 497 \\
\hline BRIDG : BR & 496.58 & 0.67 & 487.67 & 498.89 * & 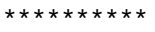 & 2.11 & 501.00 & 498. \\
\hline RDWAY : RG & $\star \star \star \star \star \star \star \star \star \star * *$ & $\star * * *$ & 499.59 & 510.31 & $0.02 * * * * * *$ & 0.11 & 502.98 & 502.4 \\
\hline
\end{tabular}


WSPRO OUTPUT FILE (continued)

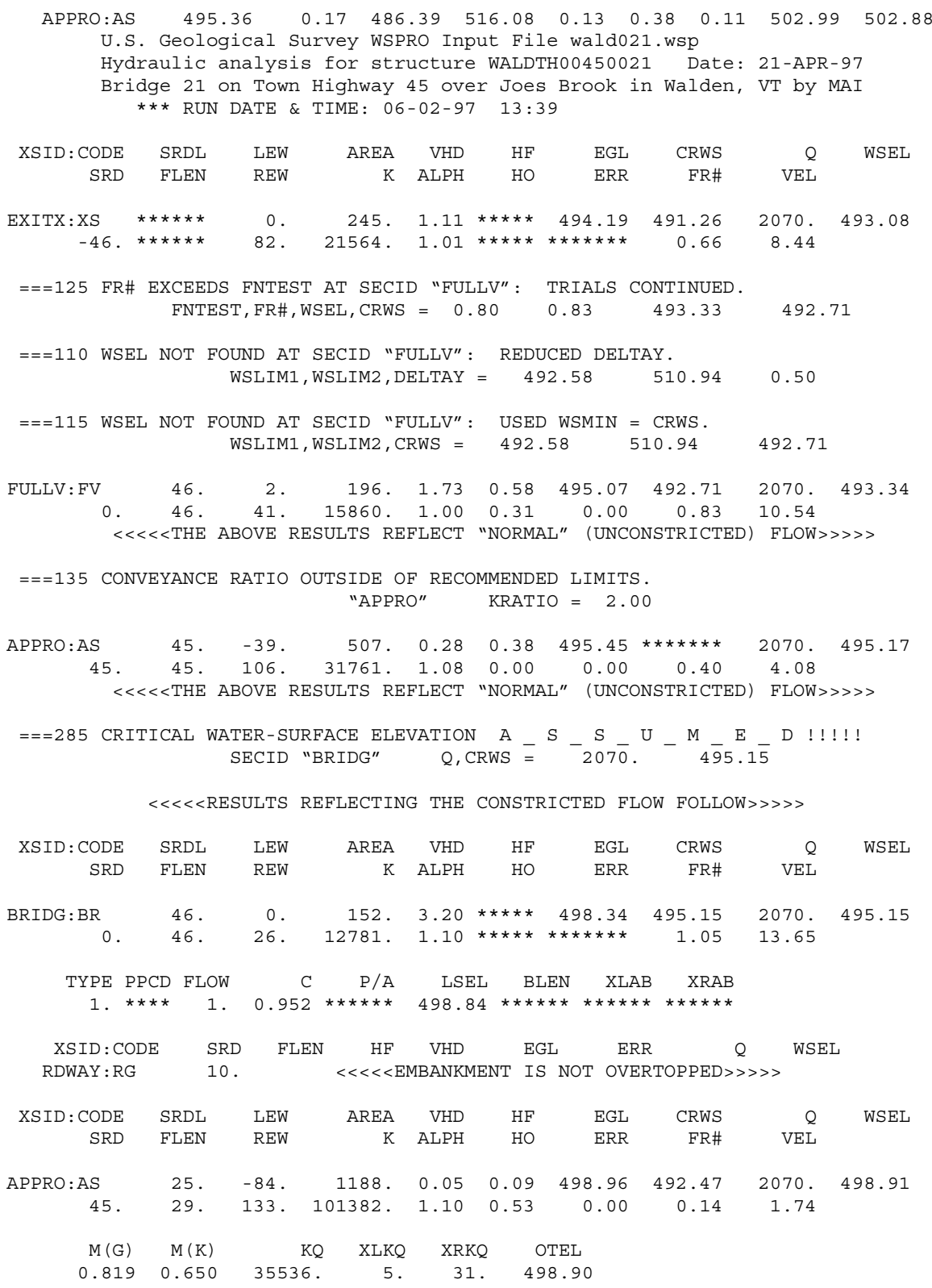

FIRST USER DEFINED TABLE.

$\begin{array}{lcccccrrr}\text { XSID : CODE } & \text { SRD } & \text { LEW } & \text { REW } & Q & \text { K } & \text { AREA } & \text { VEL } & \text { WSEL } \\ \text { EXITX : XS } & -46 . & 0 . & 82 . & 2070 . & 21564 . & 245 . & 8.44 & 493.08 \\ \text { FULLV : FV } & 0 . & 2 . & 41 . & 2070 . & 15860 . & 196 . & 10.54 & 493.34 \\ \text { BRIDG : BR } & 0 . & 0 . & 26 . & 2070 . & 12781 . & 152 . & 13.65 & 495.15 \\ \text { RDWAY : RG } & 10 . * * * * * * * * * * * * & 0 . * * * * * * * * * * * * * * & 2.00 * * * * * * * \\ \text { APPRO : AS } & 45 . & -84 . & 133 . & 2070 . & 101382 . & 1188 . & 1.74 & 498.91\end{array}$

SECOND USER DEFINED TABLE.

$\begin{array}{lrrrrrrrrr}\text { XSID : CODE } & \text { CRWS } & \text { FR\# } & \text { YMIN } & \text { YMAX } & \text { HF } & \text { HO } & \text { VHD } & \text { EGL } & \text { WSEL } \\ \text { EXITX : XS } & 491.26 & 0.66 & 485.55 & 509.48 * * * * * * * * * * & 1.11 & 494.19 & 493.08 \\ \text { FULLV : FV } & 492.71 & 0.83 & 487.01 & 510.94 & 0.58 & 0.31 & 1.73 & 495.07 & 493.34 \\ \text { BRIDG : BR } & 495.15 & 1.05 & 487.67 & 498.89 * * * * * * * * * * * & 3.20 & 498.34 & 495.15 \\ \text { RDWAY : RG } & * * * * * * * * * * * * * * * * & 499.59 & 510.31 * * * * * * * * * * * * * * * * * * * * * * * * * * * * * * * \\ \text { APPRO : AS } & 492.47 & 0.14 & 486.39 & 516.08 & 0.09 & 0.53 & 0.05 & 498.96 & 498.91\end{array}$




\section{APPENDIX C:}

\section{BED-MATERIAL PARTICLE-SIZE DISTRIBUTION}




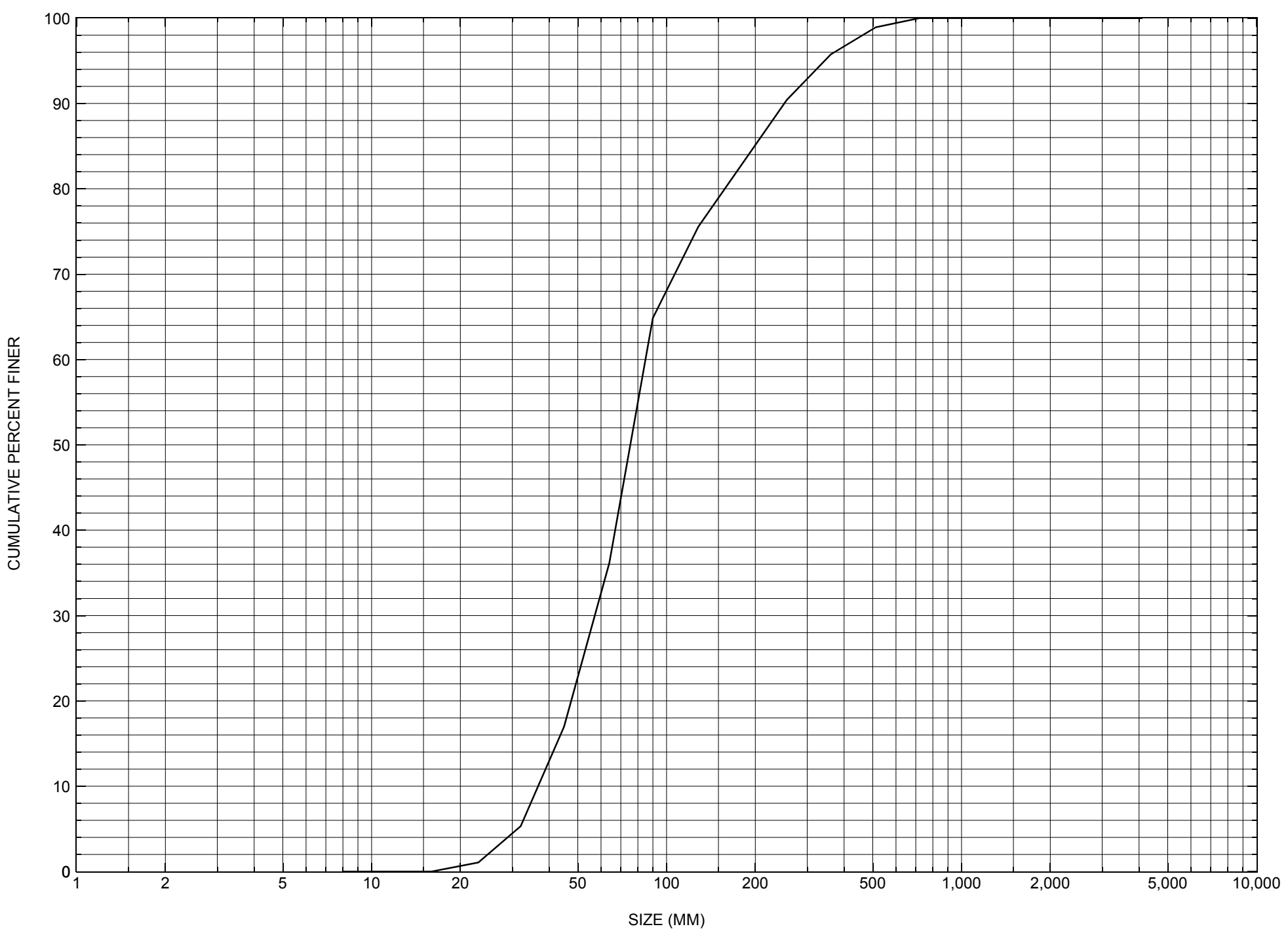

Appendix C. Bed material particle-size distribution for a pebble count in the channel approach of structure WALDTH00450021, in Walden, Vermont. 


\section{APPENDIX D: \\ HISTORICAL DATA FORM}




\section{Structure Number WALDTH00450021}

\section{General Location Descriptive}

Data collected by (First Initial, Full last name) M. IVANOFF

Date $(M M / D D / Y Y) \_\mathbf{0 4} / \underline{05} / \underline{95}$

Highway District Number (I - 2; nn) $\mathbf{0 7}$

Town (FIPS place code; I - 4; nnnnn) $\mathbf{7 5 7 0 0}$

Waterway ( $($ - 6) JOES BROOK

Route Number TH045

Topographic Map St. Johnsbury

Latitude (I - 16; nnnn.n) $\mathbf{4 4 2 6 1}$
County (FIPS county code; I - 3; nnn)

Mile marker (I - 11; nnn.nnn) $\mathbf{0 0 0 0 0 0}$

Road Name (I - 7): -

Vicinity (I - 9) 0.1 MI TO JCT W VT15

Hydrologic Unit Code: $\mathbf{0 1 0 8 0 1 0 2}$

Longitude (i - 17; nnnnn.n) $\mathbf{7 2 1 3 3}$

\section{Select Federal Inventory Codes}

FHWA Structure Number (I - 8) $\mathbf{1 0 0 3 1 5 0 0 2 1 0 3 1 5}$

Maintenance responsibility $(I-21 ; n n) \quad \mathbf{0 3} \quad$ Maximum span length (I - 48; nnnn) $\underline{\mathbf{0 0 2 9}}$

Year built (I - 27; YYYY) 1991

Structure length (I - 49; nnnnnn) $\underline{\mathbf{0 0 0 0 3 5}}$

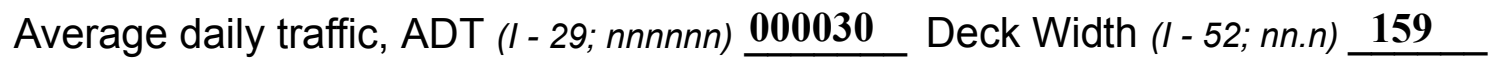

Year of ADT (I - 30; YY) $\mathbf{9 3}$

Channel \& Protection $(I-61 ; n) \quad \mathbf{6}$

Opening skew to Roadway $(I-34 ; n n) \quad \mathbf{0 0}$

Waterway adequacy $(I-71 ; n)$

Operational status $(I-41 ; X) \underline{P}$

Underwater Inspection Frequency $(I-92 B ; X Y Y) \_\mathbf{N}$

Structure type (I- 43; nnn) $\mathbf{3 0 2}$

Year Reconstructed (I - 106) $\mathbf{0 0 0 0}$

Approach span structure type (I - 44; nnn) $\mathbf{0 0 0}$ Clear span (nnn.n ft) _ _

Number of spans (I - 45; nnn) $\mathbf{0 0 1}$

Vertical clearance from streambed (nnn.n ft) $\underline{\mathbf{1 1 . 5}}$

Number of approach spans (I - 46; nnnn) $\mathbf{0 0 0 0}$

Waterway of full opening $\left(n n n . n \mathrm{ft}^{2}\right)$

Comments:

The structural inspection report of $06 / 07 / 93$ indicates the structure is a steel stringer type bridge with a wooden deck. The abutments are "laid up" concrete blocks. Some stone and boulder stone fill has been placed along the entire base length of the abutments and around the ends. The embankment has partially slid out at the downstream end of the left abutment. Some erosion along the banks is reported from past flooding. Stone fill has partially eroded away from the left abutment. 


\section{Bridge Hydrologic Data}

Is there hydrologic data available? $\underline{\mathbf{N}}$ if No, type ctrl-n $h \quad$ VTAOT Drainage area $\left(m i^{2}\right)$ : -

Terrain character:

Stream character \& type: -

Streambed material:

Discharge Data (cfs):

$$
\begin{aligned}
& Q_{2.33}- \\
& Q_{50}-
\end{aligned}
$$

Record flood date $(M M / D D / Y Y)$ :

Estimated Discharge (cfs): Ice conditions (Heavy, Moderate, Light) : -

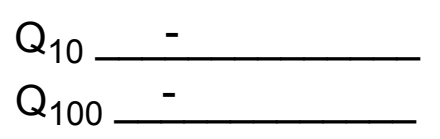

$$
\begin{aligned}
& Q_{25}- \\
& Q_{500}-
\end{aligned}
$$

Water surface elevation $(f t):-$

The stage increases to maximum highwater elevation (Rapidly, Not rapidly):

The stream response is (Flashy, Not flashy):

Describe any significant site conditions upstream or downstream that may influence the stream's stage: -

Watershed storage area (in percent): _ _ \%

The watershed storage area is: - (1-mainly at the headwaters; 2- uniformly distributed; 3-immediatly upstream oi the site)

Water Surface Elevation Estimates for Existing Structure:

\begin{tabular}{|l|l|l|l|l|l|}
\hline Peak discharge frequency & $Q_{2.33}$ & $Q_{10}$ & $Q_{25}$ & $Q_{50}$ & $Q_{100}$ \\
Water surface elevation (ft)) & - & - & - & - & - \\
Velocity (ft/sec) & - & - & - & - & - \\
\hline
\end{tabular}

Long term stream bed changes: -

Is the roadway overtopped below the $\mathrm{Q}_{100}$ ? (Yes, No, Unknown): $\mathbf{U} \quad$ Frequency: Relief Elevation (ft): Discharge over roadway at $Q_{100}\left(f^{3} / \mathrm{sec}\right)$ :

Are there other structures nearby? (Yes, No, Unknown): $\underline{\mathbf{U}}$ Upstream distance (miles): Town: If No or Unknown, type ctrl-n os Highway No. : Structure No. : Year Built:

Clear span (ft): Clear Height $(f t)$ : Full Waterway $\left(f^{2}\right)$ : 
Downstream distance (miles): Town: Year Built:

Highway No. : Structure No. : Structure Type:

Clear span (ft): Clear Height $(f t)$ : Full Waterway $\left(f^{2}\right)$ : -

Comments:

\section{USGS Watershed Data}

Watershed Hydrographic Data

Drainage area $(D A) \underline{18.73} \mathrm{mi}^{2}$

Watershed storage (ST) $\quad \mathbf{2 . 0}$

Bridge site elevation 1558

Main channel length 9.931 $10 \%$ channel length elevation 1595 $\mathrm{ft} \quad 85 \%$ channel length elevation $\mathrm{ft}$

Main channel slope $(S)$

(S) 74.4 $\mathrm{ft} / \mathrm{mi}$

Watershed Precipitation Data

Average site precipitation in Average headwater precipitation in

Maximum 2yr-24hr precipitation event $(124,2)$ in

Average seasonal snowfall (Sn) $\mathrm{ft}$ 


\section{Bridge Plan Data}

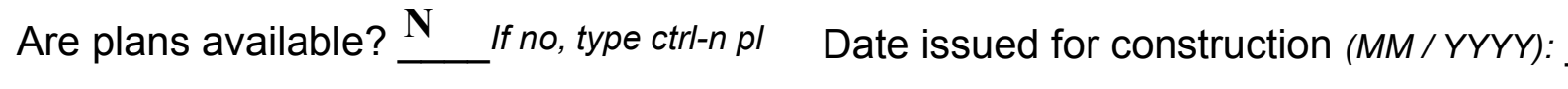

Project Number

Minimum channel bed elevation:

Low superstructure elevation: USLAB DSLAB USRAB DSRAB Benchmark location description:

NO BENCHMARK INFORMATION

Reference Point (MSL, Arbitrary, Other): Datum (NAD27, NAD83, Other):

Foundation Type: 4

If 1: Footing Thickness

If 2: Pile Type: (1-Wood; 2-Steel or metal; 3-Concrete)

If 3 : Footing bottom elevation:

Is boring information available? $\mathbf{N}$ If no, type ctrl-n bi Number of borings taken:

Foundation Material Type: $\mathbf{3}$ (1-regolith, 2-bedrock, 3-unknown)

Briefly describe material at foundation bottom elevation or around piles:

NO FOUNDATION MATERIAL INFORMATION

Comments:

NO PLANS. 


\section{Cross-sectional Data}

Is cross-sectional data available? Yes If no, type ctrl-n xs

Source (FEMA, VTAOT, Other)? VTAOT

Comments: This cross-section is of the upstream face. The low chord elevation is from the survey log done for this report on $\mathbf{0 8 / 0 7 / 9 5}$. The low chord to bed length data is from the sketch attached to a bridge inspection report dated $06 / 07 / 93$.

\begin{tabular}{|l|l|l|l|l|l|l|l|l|l|l|l|}
\hline Station & $\mathbf{0}$ & $\mathbf{8 . 7}$ & $\mathbf{1 0 . 7}$ & $\mathbf{1 5 . 7}$ & $\mathbf{2 5 . 7}$ & - & - & - & - & - & - \\
\hline Feature & LAB & - & - & - & RAB & - & - & - & - & - & - \\
\hline $\begin{array}{l}\text { Low chord } \\
\text { elevation }\end{array}$ & $\mathbf{4 9 8 . 9}$ & $\mathbf{4 9 7 . 7}$ & $\mathbf{4 9 7 . 5}$ & $\mathbf{4 9 5 . 9}$ & $\mathbf{4 9 5 . 5}$ & - & - & - & - & - & - \\
\hline $\begin{array}{l}\text { Bed } \\
\text { elevation }\end{array}$ & $\mathbf{4 9 1 . 3}$ & $\mathbf{4 8 6 . 6}$ & $\mathbf{4 8 5 . 7}$ & $\mathbf{4 8 5 . 4}$ & $\mathbf{4 8 8 . 6}$ & - & - & - & - & - & - \\
\hline $\begin{array}{l}\text { Low chord- } \\
\text { bed }\end{array}$ & $\mathbf{7 . 6}$ & $\mathbf{1 1 . 1}$ & $\mathbf{1 1 . 8}$ & $\mathbf{1 1 . 5}$ & $\mathbf{6 . 9}$ & - & - & - & - & - & - \\
\hline Station & - & - & - & - & - & - & - & - & - & - & - \\
\hline Feature & - & - & - & - & - & - & - & - & - & - & - \\
\hline $\begin{array}{l}\text { Low chord } \\
\text { elevation }\end{array}$ & - & - & - & - & - & - & - & - & - & - & - \\
\hline $\begin{array}{l}\text { Bed } \\
\text { elevation }\end{array}$ & - & - & - & - & - & - & - & - & - & - & - \\
\hline $\begin{array}{l}\text { Low chord- } \\
\text { bed }\end{array}$ & - & - & - & - & - & - & - & - & - & - & - \\
\hline
\end{tabular}

Source (FEMA, VTAOT, Other)?

Comments:

\begin{tabular}{|l|l|l|l|l|l|l|l|l|l|l|l|}
\hline Station & - & - & - & - & - & - & - & - & - & - & - \\
\hline Feature & - & - & - & - & - & - & - & - & - & - & - \\
\hline $\begin{array}{l}\text { Low chord } \\
\text { elevation }\end{array}$ & - & - & - & - & - & - & - & - & - & - & - \\
\hline $\begin{array}{l}\text { Bed } \\
\text { elevation }\end{array}$ & - & - & - & - & - & - & - & - & - & - & - \\
\hline $\begin{array}{l}\text { Low chord- } \\
\text { bed }\end{array}$ & - & - & - & - & - & - & - & - & - & - & - \\
\hline Station & - & - & - & - & - & - & - & - & - & - & - \\
\hline Feature & - & - & - & - & - & - & - & - & - & - & - \\
\hline $\begin{array}{l}\text { Low chord } \\
\text { elevation }\end{array}$ & - & - & - & - & - & - & - & - & - & - & - \\
\hline $\begin{array}{l}\text { Bed } \\
\text { elevation }\end{array}$ & - & - & - & - & - & - & - & - & - & - & - \\
\hline $\begin{array}{l}\text { Low chord- } \\
\text { bed }\end{array}$ & - & - & - & - & - & - & - & - & - & - & - \\
\hline
\end{tabular}




\section{APPENDIX E: \\ LEVEL I DATA FORM}


U. S. Geological Survey

Bridge Field Data Collection and Processing Form

Qa/Qc Check by: $\underline{\mathbf{R B}}$ Date: $\mathbf{3 / 2 2 / 9 6}$

\section{Structure Number}

\section{A. General Location Descriptive}

1. Data collected by (First Initial, Full last name) $\underline{\mathbf{L}}$. Medalie

Date $(M M / D D / Y Y)$ / $27 / 1995$

2. Highway District Number 07

Mile marker 000

County Caledonia (005)

Town Walden (75700)

Waterway (I - 6) Joes Brook

Route Number TH045

Road Name -

Hydrologic Unit Code: $\mathbf{0 1 0 8 0 1 0 2}$

3. Descriptive comments:

This bridge is located 0.1 miles from the junction with VT 15. This site was revisited for Level II analysis on 8/7/95 after the high water event on $8 / 5$ and $8 / 6$; some additional comments and observations were made.

\section{B. Bridge Deck Observations}

\section{Surface cover... $\quad$ LBUS $4 \quad$ RBUS $4 \quad$ LBDS $4 \quad$ RBDS 4 Overall 4}

(2b us,ds,lb,rb: 1- Urban; 2- Suburban; 3- Row crops; 4- Pasture; 5- Shrub- and brushland; 6- Forest; 7- Wetland)

5. Ambient water surface...US $\underline{1}$ UB $\underline{2}$ DS $\underline{1}$ (1-pool; 2- riffle)

6. Bridge structure type 1 (1- single span; 2- multiple span; 3- single arch; 4- multiple arch; 5-cylindrical culvert; 6- box culvert; or 7- other)
7. Bridge length $\mathbf{3 5}$
(feet)
Span length 29
(feet)
Bridge width 15.9 (feet)

\section{Road approach to bridge:}

\section{LB 1 RB 1 ( 0 even, 1-lower, 2- higher) \\ 9. LB 2 RB 2 (1- Paved, 2- Not paved)}

10. Embankment slope (run / rise in feet / foot):

US left

US right --

\begin{tabular}{|c|c|c|c|c|}
\hline & \multicolumn{2}{|c|}{ Protection } & \multirow{2}{*}{ 13.Erosion } & \multirow{2}{*}{ 14.Severity } \\
\hline & 11.Type & 12.Cond. & & \\
\hline LBUS & $\mathbf{0}$ & - & 3 & 2 \\
\hline RBUS & 2 & 2 & 1 & 1 \\
\hline RBDS & $\mathbf{0}$ & - & 1 & 1 \\
\hline LBDS & $\mathbf{0}$ & - & 3 & 2 \\
\hline
\end{tabular}

Bank protection types: 0- none; 1- < 12 inches;

2- < 36 inches; 3- < 48 inches;

4- $<60$ inches; 5- wall / artificial levee

Bank protection conditions: 1- good; 2- slumped;

3- eroded; 4- failed

Erosion: 0 - none; 1- channel erosion; 2-

road wash; 3- both; 4- other

Erosion Severity: 0 - none; 1- slight; 2- moderate;

\section{Channel approach to bridge (BF):}

15. Angle of approach: $\mathbf{0}$

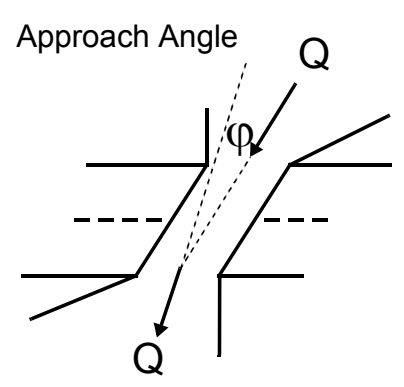

17. Channel impact zone 1 :

Where? RB (LB, RB)

Range? 15 feet US

Channel impact zone 2:

Where? - $\quad(L B, R B)$

Range? - $\quad$ feet -

(US, UB, DS) to Impact Severity: 0- none to very slight; 1- Slight; 2- Moderate; 3- Severe feet -

16. Bridge skew: $\mathbf{0}$ Bridge Skew Angle

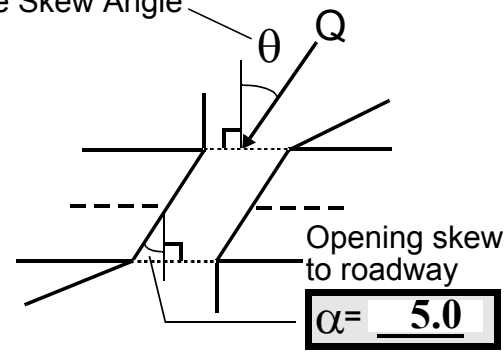

\section{Exist? $\underline{\mathbf{Y}}(\mathrm{Y}$ or $N)$}

Severity 2

(US, UB, DS) to 25 feet $\underline{\mathbf{U S}}$

Exist? $\underline{\mathbf{N}}(\mathrm{Y}$ or $N)$

Severity - 
18. Bridge Type: $\mathbf{1 b}$

1a- Vertical abutments with wingwalls

$1 \mathrm{~b}$ - Vertical abutments without wingwalls

2- Vertical abutments and wingwalls, sloping embankment Wingwalls parallel to abut. face

3- Spill through abutments

4- Sloping embankment, vertical wingwalls and abutments

Wingwall angle less than $90^{\circ}$.

19. Bridge Deck Comments (surface cover variations, measured bridge and span lengths, bridge type variations, approach overflow width, etc.)

7. The bridge dimension values are from the VTAOT files. The measured span length is $\mathbf{2 6 . 5} \mathrm{ft}$, bridge length is $34 \mathrm{ft}$ and deck width is $\mathbf{1 5 . 9} \mathrm{ft}$.

4. On the right bank DS and US there are $30 \mathrm{ft}$ wide strips of brush and a few trees along the banks and then pasture.

8. The right road approach width is $10 \mathrm{ft}$ and the left road approach width is $11 \mathrm{ft}$.

\section{Upstream Channel Assessment}

\begin{tabular}{|c|c|c|c|c|c|c|c|c|c|c|}
\hline \multicolumn{5}{|c|}{ 21. Bank height (BF) 22. Bank angle (BF) } & \multicolumn{2}{|c|}{ cover (BF) } & \multicolumn{2}{|c|}{ 27. Bank material (BF) } & \multicolumn{2}{|c|}{ 28. Bank erosion (BF } \\
\hline 20. SRD & LB & $\mathrm{RB}$ & LB & RB & LB & RB & LB & RB & LB & RB \\
\hline 26.5 & 5.0 & & & 3.5 & 3 & 3 & 12 & 1 & 1 & 2 \\
\hline 3. Bar & & & 24. $C$ & el width & 5.0 & 25. Th & Neg de & 2.5 & & 34 \\
\hline
\end{tabular}

30 .Bank protection type: $\quad$ LB

RB 0

31. Bank protection condition: LB 2

$\mathrm{RB}$ -

SRD - Section ref. dist. to US face \% Vegetation (Veg) cover: 1- 0 to 25\%; 2- 26 to 50\%; 3- 51 to $75 \%$; 4- 76 to $100 \%$

Bed and bank Material: 0- organics; 1- silt / clay, <1/16mm; 2- sand, 1/16 - 2mm; 3- gravel, 2 - 64mm;

4- cobble, 64 - 256mm; 5- boulder, > 256mm; 6- bedrock; 7- manmade

Bank Erosion: 0- not evident; 1- light fluvial; 2- moderate fluvial; 3- heavy fluvial / mass wasting

Bank protection types: 0- absent; 1- < 12 inches; 2- < 36 inches; 3- < 48 inches; 4- < 60 inches; 5- wall / artificial levee

Bank protection conditions: 1-good; 2- slumped; 3- eroded; 4- failed

32. Comments (bank material variation, minor inflows, protection extent, etc.):

26. The vegetation cover consists of strips of brush with a few trees along the bank. On the right bank there are no trees, only weeds from the bridge to 32 feet US. On the left bank the brush and tree cover starts at 7 feet from the bridge. 
33.Point/Side bar present? $\mathbf{N}(Y$ or $N$. if $N$ type ctrl-n pb)34. Mid-bar distance: -

35. Mid-bar width: -

36. Point bar extent: feet (US, UB) to feet (US, UB, DS) positioned $\%$ LB to $\% \mathrm{RB}$

37. Material: -

38. Point or side bar comments (Circle Point or Side; Note additional bars, material variation, status, etc.):

NO POINT BARS

39. Is a cut-bank present? $\mathbf{Y}$ (Y or if $N$ type ctrl-n cb)

40. Where? $\mathbf{R B}$ (LB or RB)

41. Mid-bank distance: $\mathbf{2 0}$

42. Cut bank extent: 15

feet $\underline{\text { US }}$ (US, UB) to $\underline{25}$ feet $\underline{\text { US }}$ (US, UB, DS)

43. Bank damage: 1

(1- eroded and/or creep; 2- slip failure; 3- block failure)

44. Cut bank comments (eg. additional cut banks, protection condition, etc.):

There is a large bend in the river beginning at about 25 feet US of the bridge.

45. Is channel scour present? $\mathbf{N}$ ( $Y$ or if $N$ type ctrl-n cs)

47. Scour dimensions: Length -

Width -

Depth : -

46. Mid-scour distance: -

48. Scour comments (eg. additional scour areas, local scouring process, etc.):

NO CHANNEL SCOUR

49. Are there major confluences? $\mathbf{N}$

51. Confluence 1: Distance -

Confluence 2: Distance -

52. Enters on -

Enters on -

54. Confluence comments (eg. confluence name):

NO MAJOR CONFLUENCES
50. How many? -

53. Type(1-perennial; 2- ephemeral)

Type (1-perennial; 2-ephemeral) (LB or $R B)$

\section{Under Bridge Channel Assessment}

55. Channel restraint (BF)? LB 2

\begin{tabular}{|ccccc|}
\hline \multicolumn{3}{|c}{ 56. Height (BF) } & \multicolumn{3}{c}{57 Angle (BF) } \\
LB & RB & LB & RB \\
$\mathbf{3 7 . 5}$ & & & $\mathbf{5 . 5}$ & \\
\hline
\end{tabular}

58. Bank width (BF) (1- natural bank; 2- abutment; 3- artificial levee)

Bed and bank Material: 0- organics; 1- silt / clay, < 1/16mm; 2- sand, 1/16 - 2mm; 3- gravel, 2 - 64mm; 4- cobble, 64 - 256mm; 5- boulder, > 256mm; 6- bedrock; 7- manmade

61. Material $(\mathrm{BF}) \quad$ 62. Erosion $(\mathrm{BF})$

LB RB LB RB

$\underline{2} \quad \mathbf{7} \quad \underline{7} \quad \underline{-}$

59. Channel width - 60. Thalweg depth $\lcm{\mathbf{9 0 . 0}}$

63. Bed Material -

Bank Erosion: 0- not evident; 1- light fluvial; 2- moderate fluvial; 3- heavy fluvial / mass wasting

64. Comments (bank material variation, minor inflows, protection extent, etc.):

2345

There is significant variability of the bed material. At the US end of the bridge, just below the bridge deck there is a row of cobbles and boulders extending across the channel to form a small drop structure. The water level differs US and DS of this structure by about 1 foot. 
65. Debris and Ice Is there debris accumulation?

67. Debris Potential ( 1- Low; 2- Moderate; 3- High)

69. Is there evidence of ice build-up? 1 (Y or N)

70. Debris and Ice Comments:
$(Y$ or $N)$ 66. Where? $\mathbf{N}$

68. Capture Efficiency 1

(1- Upstream; 2- At bridge; 3-Both)

Ice Blockage Potential $\mathbf{N}$
(1-Low; 2- Moderate; 3- High)

(1-Low; 2- Moderate; 3- High) 1

\begin{tabular}{|l|c|c|c|c|c|c|c|c|}
\hline Abutments & $\begin{array}{c}\text { 71. Attack } \\
\angle \text { (BF) }\end{array}$ & $\begin{array}{c}\text { 72. Slope } \angle \\
\text { (Qmax) }\end{array}$ & $\begin{array}{c}\text { 73. Toe } \\
\text { loc. (BF) }\end{array}$ & $\begin{array}{c}\text { 74. Scour } \\
\text { Condition }\end{array}$ & $\begin{array}{c}75 . \text { Scour } \\
\text { depth }\end{array}$ & $\begin{array}{c}\text { 76. Exposure } \\
\text { depth }\end{array}$ & 77. Material & 78. Length \\
\hline LABUT & & $\mathbf{0}$ & $\mathbf{9 0}$ & $\mathbf{2}$ & $\mathbf{0}$ & - & - & $\mathbf{9 0 . 0}$ \\
\hline RABUT & $\mathbf{1}$ & $\mathbf{0}$ & $\mathbf{9 0}$ & & & $\mathbf{2}$ & $\mathbf{0}$ & $\mathbf{2 5 . 5}$ \\
\hline
\end{tabular}

Pushed: $L B$ or RB

Toe Location (Loc.): 0- even, 1- set back, 2- protrudes

Scour cond.: 0- not evident; 1- evident (comment); 2- footing exposed; 3-undermined footing; 4- piling exposed; 5- settled; 6- failed

Materials: 1- Concrete; 2- Stone masonry or drywall; 3- steel or metal; 4- wood

79. Abutment comments (eg. undermined penetration, unusual scour processes, debris, etc.):

$-$

1

The abutment material consist of "laid-up" concrete blocks; 2 ft X 4 ft X 4 ft.

80. Wingwalls:

Exist? Material? $\begin{gathered}\text { Scour } \\ \text { Condition? }\end{gathered}$ depth? $\begin{array}{lll}81 . & & \\ & \text { depth? } & \text { Angle? Length? }\end{array}$

USLWW:

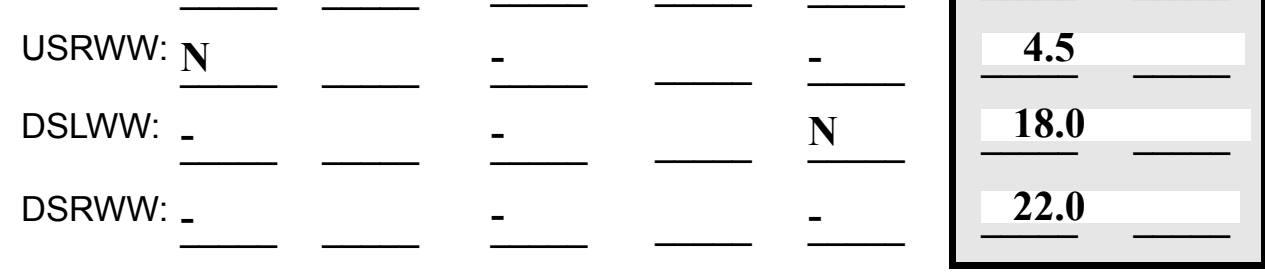

Wingwall materials: 1- Concrete; 2- Stone masonry or drywall; 3- steel or metal; 4- wood

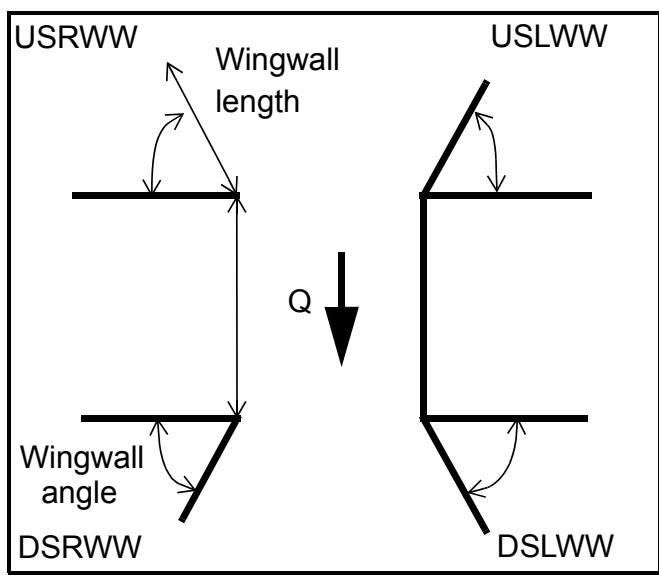

82. Bank / Bridge Protection:

\begin{tabular}{|l|l|l|l|l|l|l|l|c|}
\hline Location & USLWW & USRWW & LABUT & RABUT & LB & RB & DSLWW & DSRWW \\
\hline Type & - & - & N & - & - & - & $\mathbf{1}$ & $\mathbf{1}$ \\
\hline Condition & N & - & - & - & - & - & $\mathbf{1}$ & $\mathbf{1}$ \\
\hline Extent & - & - & - & - & - & $\mathbf{1}$ & $\mathbf{2}$ & - \\
\hline
\end{tabular}

Bank / Bridge protection types: 0- absent; 1- < 12 inches; 2- < 36 inches; 3- < 48 inches; 4- < 60 inches; 
83. Wingwall and protection comments (eg. undermined penetration, unusual scour processes, etc.):

-
-
-
-
-
-
-
-

\section{Piers:}

84. Are there piers? _ _ (Y or if $N$ type ctrl-n pr)

\begin{tabular}{|l|l|l|l|l|l|l|l|}
\hline \multirow{2}{*}{$\begin{array}{l}85 . \\
\text { Pier no. }\end{array}$} & \multicolumn{3}{|c|}{ width (w) feet } & \multicolumn{3}{c|}{ elevation (e) feet } \\
\cline { 2 - 9 } & w1 & w2 & w3 & e@w1 & e@w2 & e@w3 \\
\hline Pier 1 & - & - & - & - & - & - \\
\hline Pier 2 & - & - & - & - & - & - \\
\hline Pier 3 & - & - & - & - & - & - & - \\
\hline Pier 4 & - & - & - & - & - & w1 \\
\hline
\end{tabular}

\begin{tabular}{|l|l|l|l|l|}
\hline Level 1 Pier Descr. & 1 & \multicolumn{1}{|c|}{2} & 3 & \multicolumn{1}{|c|}{} \\
\hline 86. Location (BF) & & - & - & - \\
\hline 87. Type & & - & - & - \\
\hline 88. Material & & - & - & - \\
\hline 89. Shape & & - & - & - \\
\hline 90. Inclined? & & - & - & - \\
\hline 91. Attack $\angle$ (BF) & & - & - & - \\
\hline 92. Pushed & & - & - & - \\
\hline 93. Length (feet) & - & - & - & - \\
\hline 94. \# of piles & & - & - & - \\
\hline 95. Cross-members & & - & - & - \\
\hline 96. Scour Condition & & - & - & - \\
\hline 97. Scour depth & $\mathbf{N}$ & - & - & - \\
\hline 98. Exposure depth & - & - & - & - \\
\hline
\end{tabular}

LFP, LTB, LB, MCL, MCM, MCR, RB, RTB, RFP

1- Solid pier, 2- column, 3- bent

1-Wood; 2- concrete; 3- metal; 4- stone

1- Round; 2- Square; 3- Pointed

Y-yes; $N$ - no

$L B$ or $R B$

0- none; 1- laterals; 2- diagonals; 3- both

0- not evident; 1- evident (comment);

2- footing exposed; 3- piling exposed;

4- undermined footing; 5- settled; 6- failed 
99. Pier comments (eg. undermined penetration, protection and protection extent, unusual scour processes, etc.):

-
-
-
-
-
-
-
-
-
-

100.

\section{E. Downstream Channel Assessment}

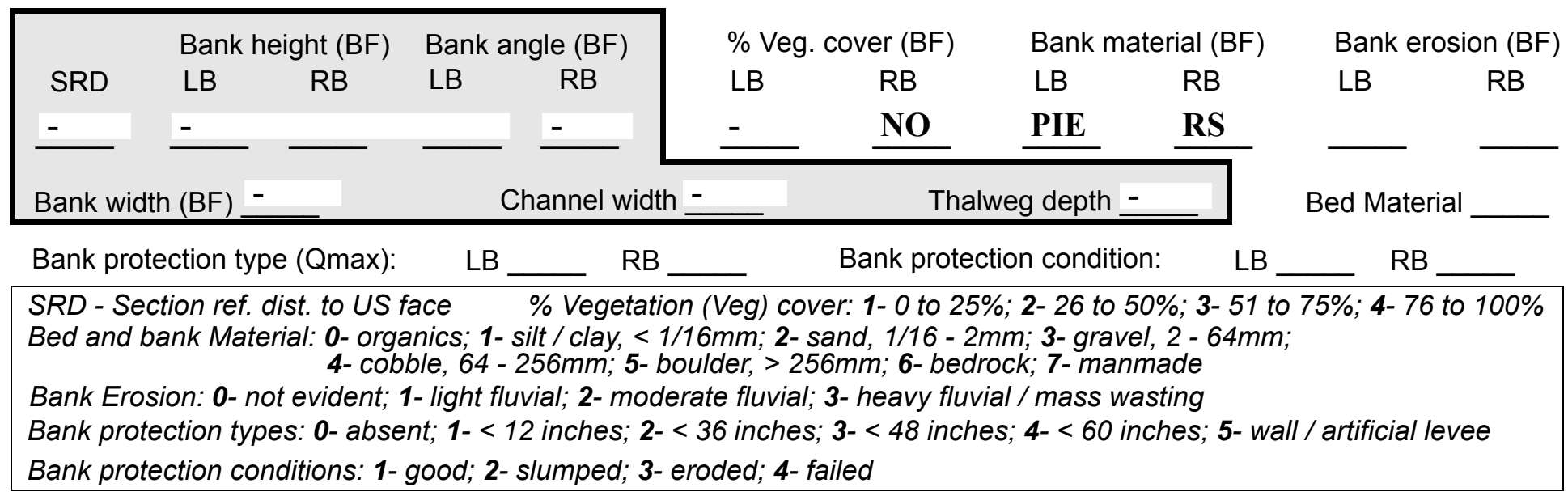

Comments (eg. bank material variation, minor inflows, protection extent, etc.):

1

2

12

12

1

2

3245

0

0

The DS thalweg measures greater than $6 \mathrm{ft}$. About 100 feet DS of the bridge the depth increases to greater than 8 feet.

101. Is a drop structure present? _ _ ( or $N$, if $N$ type ctrl-n ds) 102. Distance: ___ feet
103. Drop: - feet
104. Structure material:
(1- steel sheet pile; 2- wood pile; 3- concrete; 4- other)

105. Drop structure comments (eg. downstream scour depth): 
Point bar extent: feet

(US, UB, DS) to $\underline{\mathbf{N}}$ feet (US, UB, DS)

DS) positioned \%LB to DR \%RB

Material: $\mathbf{O P}$

Point or side bar comments (Circle Point or Side; note additional bars, material variation, status, etc.):

\section{STRUCTURE}

Is a cut-bank present? (Y or if $N$ type ctrl-n cb) Where? (LB or $R B)$

Mid-bank distance: $\underline{\mathbf{N}}$

Cut bank extent: feet (US, UB, DS) to feet (US, UB, DS)

Bank damage: (1- eroded and/or creep; 2- slip failure; 3- block failure)

Cut bank comments (eg. additional cut banks, protection condition, etc.):

-

-

$-$

-

Is channel scour present? NO (Y or if N type ctrl-n cs) Mid-scour distance: $\underline{\text { POIN }}$

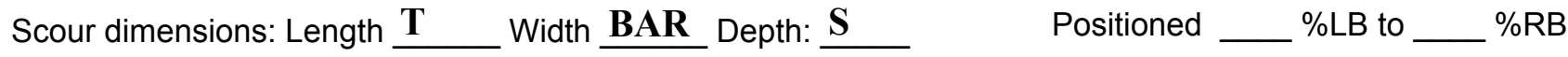

Scour comments (eg. additional scour areas, local scouring process, etc.):

$\mathbf{N}$

$-$

Are there major confluences? (Y or if $N$ type ctrl-n $m c)$

How many? -

Confluence 1: Distance Enters on ( $L B$ or $R B)$

Type (1- perennial; 2- ephemeral)

Confluence 2: Distance NO Enters on $\underline{\mathbf{C U}}$ (LB or RB)

Type $\underline{\mathbf{T}}$ (1- perennial; 2- ephemeral) Confluence comments (eg. confluence name):

\section{BANKS}

\section{F. Geomorphic Channel Assessment}

107. Stage of reach evolution

1- Constructed

2- Stable

3- Aggraded

4- Degraded

5- Laterally unstable

6- Vertically and laterally unstable 
108. Evolution comments (Channel evolution not considering bridge effects; See HEC-20, Figure 1 for geomorphic descriptors):

$\mathbf{N}$

$-$

$-$

$-$

$-$

$-$

NO CHANNEL SCOUR

$\mathbf{N}$ 


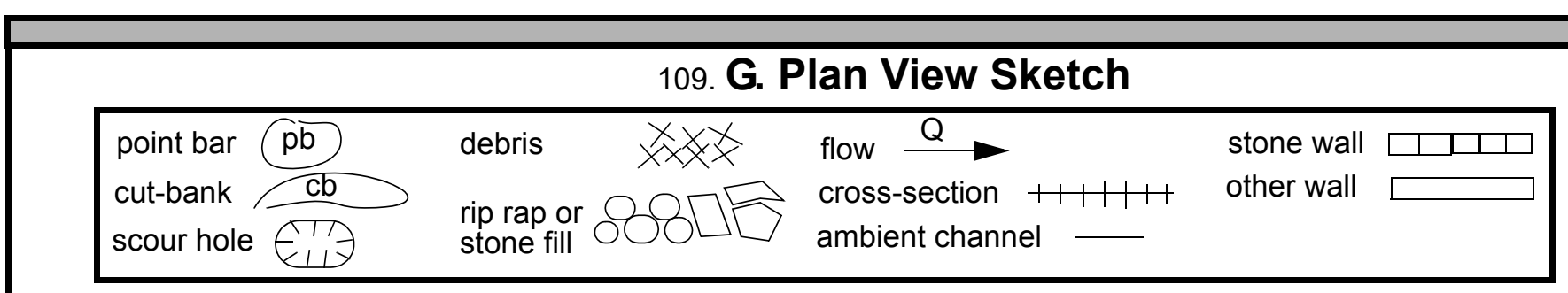


APPENDIX F:

SCOUR COMPUTATIONS 


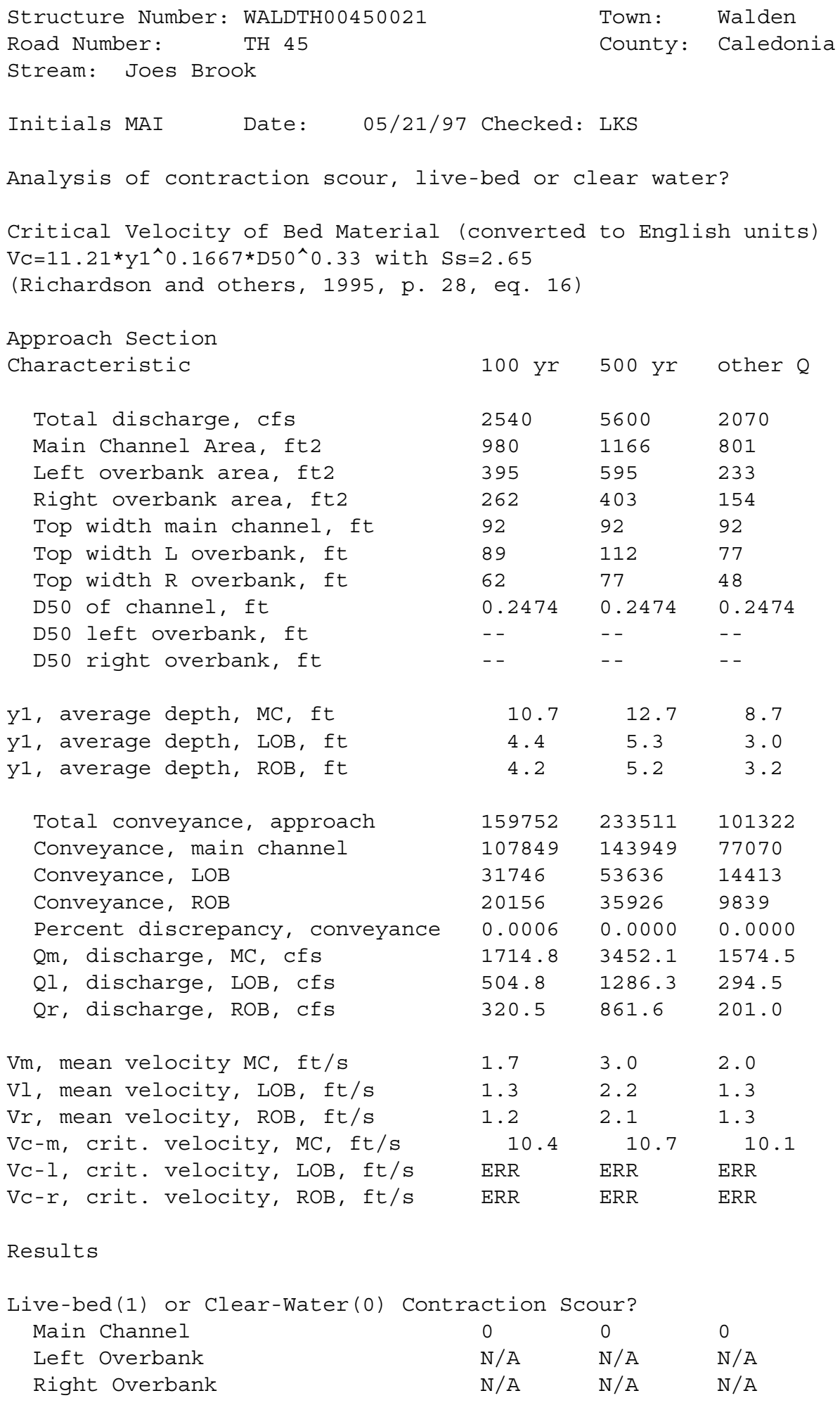


Clear Water Contraction Scour in MAIN CHANNEL

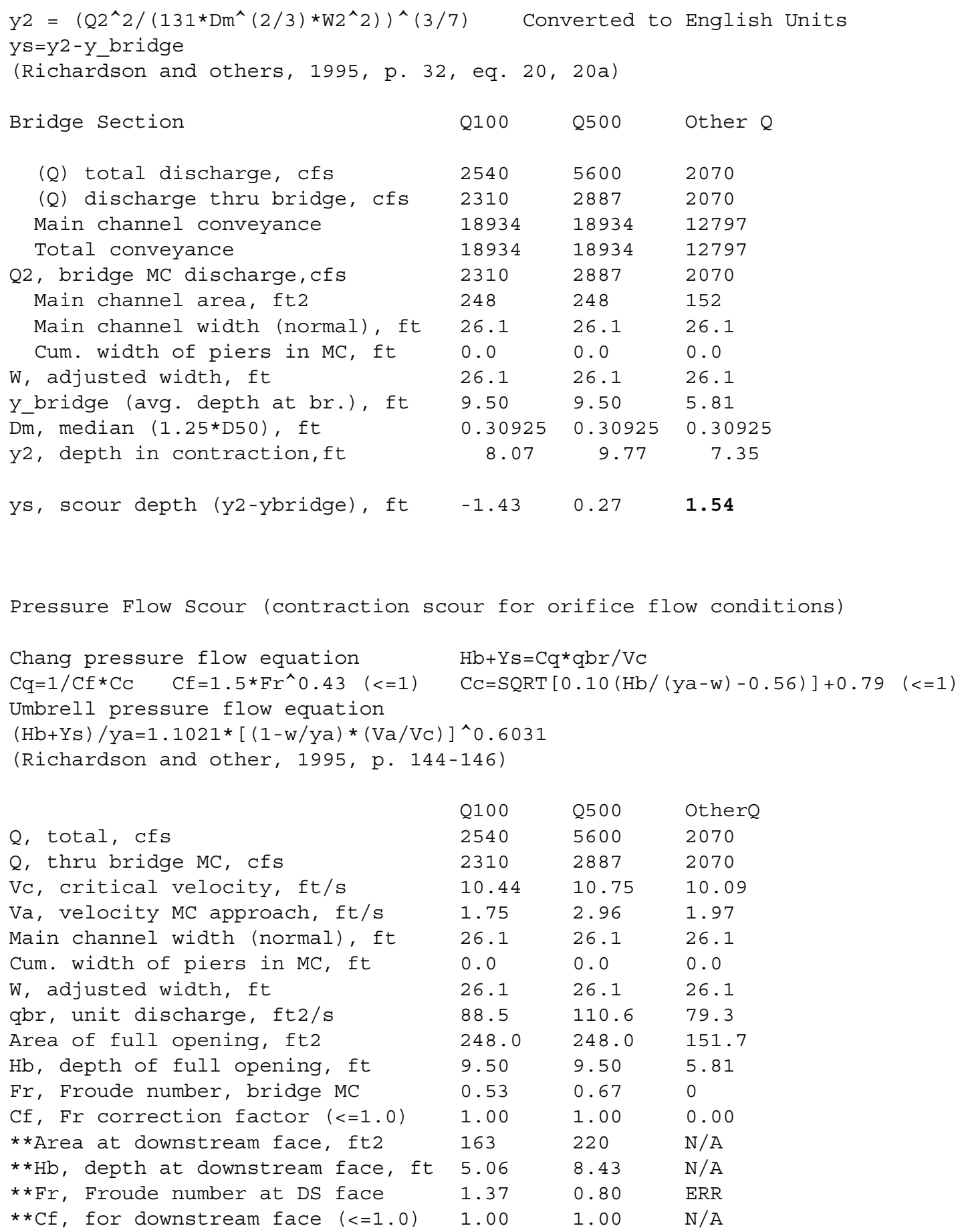




$\begin{array}{llll}\text { Elevation of Low Steel, ft } & 498.84 & 498.84 & 0 \\ \text { Elevation of Bed, ft } & 489.34 & 489.34 & -5.81 \\ \text { Elevation of Approach, ft } & 500.86 & 502.88 & 0 \\ \text { Friction loss, approach, ft } & 0.06 & 0.13 & 0 \\ \text { Elevation of WS immediately US, ft } & 500.80 & 502.75 & 0.00 \\ \text { ya, depth immediately US, ft } & 11.46 & 13.41 & 5.81 \\ \text { Mean elevation of deck, ft } & 501.28 & 501.28 & 0 \\ \text { w, depth of overflow, ft (>=0) } & 0.00 & 1.47 & 0.00 \\ \text { Cc, vert contrac correction (<=1.0) } & 0.95 & 0.94 & 1.00 \\ \text { **C, for downstream face (<=1.0) } & 0.79 & 0.910766 & \text { ERR } \\ \text { Ys, scour w/Chang equation, ft } & -0.61 & 1.41 & \text { N/A } \\ \text { Ys, scour w/Umbrell equation, ft } & -5.20 & -3.17 & \text { N/A }\end{array}$

**=for UNsubmerged orifice flow using estimated downstream bridge face properties.

**Ys, scour w/Chang equation, ft $4.49 \quad 2.87 \quad \mathrm{~N} / \mathrm{A}$

**Ys, scour w/Umbrell equation, ft $-0.76 \quad-2.10 \quad$ ERR

In UNsubmerged orifice flow, an adjusted scour depth using the Laursen

equation results and the estimated downstream bridge face properties

can also be computed (ys=y2-ybridgeDS)

Y2, from Laursen's equation, ft $31.23 \quad 25.98$ LOOK-UP

WSEL at downstream face, ft $495.59 \quad 497.76 \quad--$

Depth at downstream face, ft $6.25 \quad 8.43 \quad \mathrm{~N} / \mathrm{A}$

Ys, depth of scour (Laursen), ft $24.98 \quad 17.55$ ERR

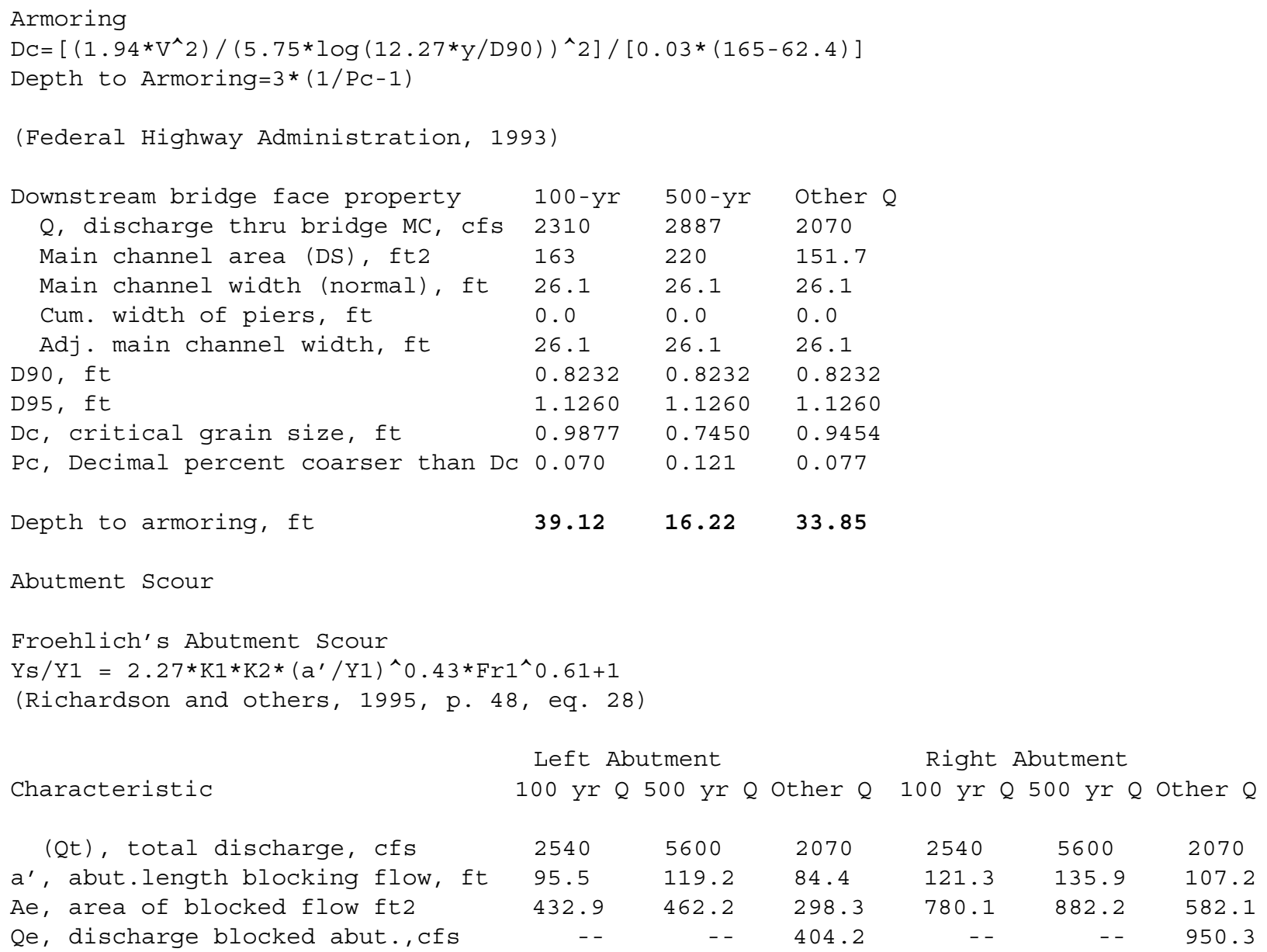


(If using Qtotal_overbank to obtain Ve, leave Qe blank and enter Ve and Fr manually)

\begin{tabular}{|c|c|c|c|c|c|c|}
\hline Ve, $(Q e / A e), \mathrm{ft} / \mathrm{s}^{-}$ & 1.32 & 2.22 & 1.36 & 1.48 & 2.53 & 1.63 \\
\hline ya, depth of $f / p$ flow, ft & 4.53 & 3.88 & 3.53 & 6.43 & 6.49 & 5.43 \\
\hline --Coeff., K1, for abut. type (1.0, & verti. & $.82, \mathrm{ve}$ & i. w/ & gwall; & 55, sp & thrr \\
\hline & 1 & 1 & 1 & 1 & 1 & 1 \\
\hline --Angle (theta) of embankment $(<90$ & if abut & points & $i>90$ & abut. & nts US & \\
\hline theta & 85 & 85 & 85 & 95 & 95 & 95 \\
\hline K2 & 0.99 & 0.99 & 0.99 & 1.01 & 1.01 & 1.01 \\
\hline Fr, froude number $f / p$ flow & 0.104 & 0.162 & 0.127 & 0.101 & 0.159 & 0.1 \\
\hline ys, scour depth, ft & 14.06 & 16.43 & 12.39 & 19.27 & 24.37 & 17 \\
\hline \multicolumn{7}{|l|}{$\begin{array}{l}\text { HIRE equation }\left(a^{\prime} / \mathrm{ya}>25\right) \\
\mathrm{ys}=4 * \mathrm{Fr}^{\wedge} 0.33 * \mathrm{y} 1 * \mathrm{~K} / 0.55\end{array}$} \\
\hline \multirow{5}{*}{$\begin{array}{l}\text { a' (abut length blocked, ft) } \\
\text { y1 (depth f/p flow, ft) } \\
\text { a'/y1 } \\
\text { Skew correction (p. 49, fig. 16) } \\
\text { Froude no. f/p flow } \\
\text { Ys w/ corr. factor K1/0.55: }\end{array}$} & 95.5 & 119.2 & 84.4 & 121.3 & 135.9 & 107 \\
\hline & 4.53 & 3.88 & 3.53 & 6.43 & 6.49 & 5.43 \\
\hline & 21.07 & 30.74 & 23.88 & 18.86 & 20.93 & 19 \\
\hline & 0.98 & 0.98 & 0.98 & 1.01 & 1.01 & 1.01 \\
\hline & 0.10 & 0.16 & 0.13 & 0.10 & 0.16 & 0.12 \\
\hline $\begin{array}{c}\text { Ys w/ corr. factor K1/0.55: } \\
\text { vertical }\end{array}$ & ERR & 15.16 & ERR & ERR & ERR & $E R R$ \\
\hline vertical w/ ww's & ERR & 12.43 & ERR & ERR & ERR & ERR \\
\hline spill-through & ERR & 8.34 & ERR & ERR & ERR & ERR \\
\hline
\end{tabular}

Abutment riprap sizing

Isbash Relationship

$\mathrm{D} 50=\mathrm{Y} * \mathrm{~K} * \mathrm{Fr} \wedge 2 /(\mathrm{Ss}-1)$ and $\mathrm{D} 50=\mathrm{Y} * \mathrm{~K} *\left(\mathrm{Fr} r^{\wedge} 2\right)^{\wedge} 0.14 /(\mathrm{Ss}-1)$

(Richardson and others, 1995, p112, eq. 81,82)

Downstream bridge face property Q100 Q500 Other Q Q100 Q500 Other Q

Fr, Froude Number $\quad \begin{array}{llllll}1.37 & 0.8 & 1.05 & 1.37 & 0.8 & 1.05\end{array}$

$y$, depth of flow in bridge, ft $\quad \begin{array}{llllll}5.06 & 8.43 & 5.81 & 5.06 & 8.43 & 5.81\end{array}$

Median Stone Diameter for riprap at: left abutment right abutment, ft Fr<=0.8 (vertical abut.) $\quad$ ERR $30 \begin{array}{llllll}3.34 & \text { ERR } & \text { ERR } & 3.34 & \text { ERR }\end{array}$

$\begin{array}{lllllll}\text { Fr }>0.8 \text { (vertical abut.) } & 2.31 & \text { ERR } & 2.46 & 2.31 & \text { ERR } & 2.46\end{array}$ 
